\title{
The ligand-mediated nuclear mobility and interaction with estrogen-responsive elements of estrogen receptors are subtype specific
}

\author{
Mesut Muyan ${ }^{1}$, Linda M Callahan ${ }^{2}$, Yanfang Huang ${ }^{1}$ and Andrew J Lee ${ }^{1}$ \\ Departments of ${ }^{1}$ Biochemistry and Biophysics and ${ }^{2}$ Pathology, University of Rochester Medical School, Rochester, New York 14642, USA \\ (Correspondence should be addressed to M Muyan who is now at Department of Biological Sciences, Middle East Technical University, Ankara, Turkey; \\ Email: mesut_muyan@urmc.rochester.edu)
}

\begin{abstract}
$17 \beta$-Estradiol $\left(E_{2}\right)$ plays important roles in functions of many tissues. $E_{2}$ effects are mediated by estrogen receptor (ER) $\alpha$ and $\beta$. ERs regulate transcriptions through estrogen-responsive element (ERE)-dependent and ERE-independent modes of action. ER binding to ERE constitutes the basis of the ERE-dependent pathway. Direct/indirect ER interactions with transcription complexes define ERE-independent signaling. ERs share functional features. Ligand-bound ERs nevertheless induce distinct transcription profiles. Live cell imaging indicates a dynamic nature of gene expressions by highly mobile ERs. However, the relative contribution of ER mobility at the ERE-independent pathway to the overall kinetics of ER mobility remains undefined. We used fluorescent recovery after a photo-bleaching approach to assess the ligand-mediated mobilities of ERE binding-defective ERs, $E R_{E B D}$. The decrease in ER $\alpha$ mobility with $\mathrm{E}_{2}$ or the selective ER modulator 4-hydroxyl-tamoxifen (4HT) was largely due to the interaction of the receptor with ERE. Thus, ER $\alpha$ bound to $\mathrm{E}_{2}$ or $4 \mathrm{HT}$ mediates transcriptions from the ERE-independent pathway with remarkably fast kinetics that contributes fractionally to the overall motility of the receptor. The antagonist Imperial Chemical Industries $182780 \mathrm{immobilized} \mathrm{ER} \alpha \mathrm{s}$. The mobilities of $E R \beta$ and $E R \beta_{E B D}$ in the presence of ligands were indistinguishable kinetically. Thus, $E R \beta$ mobility is independent of the nature of ligands and the mode of interaction with target sites. Chimeric ERs indicated that the carboxyl-termini are critical regions for subtype-specific mobility. Therefore, while ERs are highly mobile molecules interacting with target sites with fast kinetics, an indication of the hit-and-run model of transcription, they differ mechanistically to modulate transcriptions.
\end{abstract}

Journal of Molecular Endocrinology (2012) 49, 249-266

\section{Introduction}

$17 \beta$-Estradiol $\left(\mathrm{E}_{2}\right)$ plays critical roles in many physiological and pathophysiological processes of a wide range of tissues (Huang et al. 2005a, Zhao et al. 2010). $\mathrm{E}_{2}$ effects are primarily mediated by transcription factors, estrogen receptor (ER) $\alpha$ and $\beta$, that convey $\mathrm{E}_{2}$ signaling through estrogen-responsive element (ERE)-dependent and -independent pathways.

Kinetic biochemical assays indicate that the unliganded $\mathrm{ER} \alpha$ interacts, albeit inefficiently, with EREs cyclically with a time scale of $20 \mathrm{~min}$ (Shang et al. 2000, Metivier et al. 2003, Reid et al. 2003). The binding of $\mathrm{E}_{2}$ to $\mathrm{ER} \alpha$ leads to a structural reorganization that increases the stability of the ER $\alpha$ dimer (Tamrazi et al. 2002) and the affinity of $\mathrm{ER} \alpha$ to co-regulatory proteins (Yi et al. 2002b, Tamrazi et al. 2005). The interaction of $\mathrm{E}_{2}-\mathrm{ER} \alpha$ with ERE extends the duration of promoter engagement to 40-60 min (Shang et al. 2000, Metivier et al. 2003, Reid et al. 2003). This is due to the sequential recruitment of preformed co-regulator complexes for initiation and the subsequent dissociation of complexes from promoter for termination of transcription
(Shang et al. 2000, Metivier et al. 2003, Reid et al. 2003). This episodic ER $\alpha$-ERE engagement led to the transcriptional ratchet model that suggests ordered and directional events for ERE-driven gene expressions.

Fluorescent protein technologies together with quantitative live cell imaging also indicate a dynamic transcriptional regulation (Stenoien et al. 2000, 2001a,b, Sharp et al. 2006, Zwart et al. 2010). These approaches demonstrated that unliganded ER $\alpha$ exhibits rapid rates of exchange with chromatin, residence time measured in milliseconds. Although the binding of $\mathrm{E}_{2}$ to $\mathrm{ER} \alpha$ decreases the mobility of the receptor, the exchange still occurs in seconds, in a clear contrast with longer cycling times determined by kinetic biochemical assays. These fast interactions of $\mathrm{ER} \alpha$ with promoters support the alternative hit-and-run model for transcription.

Along with $\mathrm{E}_{2}$, the activity of $\mathrm{ER} \alpha$ is modulated by the selective ER modulator (SERM) tamoxifen and antagonist Imperial Chemical Industries 182780 (ICI) (McDonnell 1999). The binding of SERMs or antagonists to $\mathrm{ER} \alpha$ alters the nuclear mobility and the ability of $\mathrm{ER} \alpha$ to interact with co-regulators and chromatin (McDonnell 1999, Stenoien et al. 2001b, Yi et al. 2002b).

DOI: 10.1530/JME-12-0097 Online version via http://www.endocrinology-journals.org 
$\mathrm{E}_{2}$-ERs also regulate transcription by interacting with transcription factors (Kushner et al. 2000, Safe 2001). This nuclear signaling route is called the ERE-independent signaling pathway, which participates in the fine-tuning of cellular responses by regulating the expression of a subset of estrogenresponsive genes ( $\mathrm{Li}$ et al. 2008, Nott et al. 2009). However, the underlying mechanisms or the kinetics of events at the ERE-independent signaling pathway remains poorly defined.

Although encoded by a distinct gene, ER $\beta$ shares structural features with ER $\alpha$ reflected in similar mode of action through signaling pathways (Huang et al. 2011). ER $\beta$, nevertheless, regulates transcription with distinct potency and profile in response to ligands at signaling pathways (Huang et al. 2005a, Zhao et al. 2010). As the nuclear mobility is the sum of ER actions at target sites on chromatin, we addressed how ligands affect the nuclear mobility of an ERE binding-defective ER variant $\left(E R \alpha_{\mathrm{EBD}}\right.$ or $\left.\mathrm{ER} \beta_{\mathrm{EBD}}\right)$ that functions exclusively at the ERE-independent pathway to obtain initial insights into mechanisms of ER-mediated gene expressions. To address this issue, we used green fluorescence protein (GFP) fusion-ERs and fluorescent recovery after a photo-bleaching (FRAP) approach.

We found that the ligand-mediated nuclear mobility of $E R \alpha$ largely reflects the ability of the receptor to interact with ERE, whereas the mobility of ER $\beta$ is independent of the nature of ligands and the ability of ER $\beta$ to bind to ERE. Thus, ERs are highly mobile molecules interacting with target sites with fast kinetics, an indication of the hit-and-run model of transcription, and they differ mechanistically to modulate transcriptions.

\section{Materials and methods}

\section{Plasmids}

The expression vectors bearing human $\mathrm{ER} \alpha$ and $\mathrm{ER} \beta$ cDNAs encoding 595 and 530 amino acid long receptors respectively and the cDNA encoding the designer transcription factor PPVV were described previously (Yi et al. 2002a, Huang et al. 2004). The AF2 mutant of $\mathrm{ER} \alpha$ contains a three amino acid replacement (D538A, E542A, and D545A) that blocks the ligand-dependent activation function (AF2) of ER $\alpha$ (Tzukerman et al. 1994, Sathya et al. 2002, Yi et al. 2002a). We initially used an AF2 mutant of ER $\beta$ that contains analogous mutations to that of $\mathrm{ER} \alpha$ as we described previously (Yi et al. 2002a). However, the presence of the GFP at the amino-terminus of this mutant renders the receptor toxic to cells as they died before experimentation. To circumvent this problem, we used a point mutation that changes only the Glu residue at position 493 to a Lys in ER $\beta$ that prevents AF2
(An et al. 1999). The $\mathrm{ER}_{\mathrm{EBD}}$ were described previously (Li et al. 2008, Nott et al. 2009). The ER $\alpha_{\mathrm{EBD}}$ contains Ala, Ala, and Glu residues at positions 203, 204, and 211 respectively that replace Glu, Gly, and Arg at the corresponding positions in the DNA recognition helix of the first zinc finger critical for ER $\alpha$-ERE interactions (Nott et al. 2009). The replacement of Glu and Gly at positions 167 and 168 respectively in the DBD of $\operatorname{ER} \beta$ with Ala residues generates the $\operatorname{ER} \beta_{\mathrm{EBD}}(\mathrm{Li}$ et al. 2008). The chimeric $\mathrm{ER} \alpha_{\mathrm{N}} \beta_{\mathrm{C}}$ or $\mathrm{ER} \beta_{\mathrm{N}} \alpha_{\mathrm{C}}$, generated by genetically exchanging sequences that encode the entire amino-terminal region of ER $\beta$ or ER $\alpha$ with that of ER $\alpha$ or ER $\beta$, were also described previously (Yi et al. 2002a). cDNAs also contain sequences that encode a Flag epitope at the amino-terminus.

For the engineering of GFP fusion proteins, a restriction enzyme site was engineered at the $5^{\prime}$ of the start codon of ER cDNAs using an overlapping PCR. The engineered cDNAs were inserted into the $3^{\prime}$ end of the reading frame of the GFP-cDNA in the pAcGFP-C1 expression vector (Clontech) with appropriate restriction enzyme sites. For comparative analysis of GFP-ERs in some biochemical assays, we also generated a GFP cDNA with sequences that encode a Flag epitope at the amino-terminus of the protein. All constructs were sequenced to ensure the fidelity of encoding sequences.

We assessed the effect of ligands on ERE-driven gene expression using reporter vectors that emulate the ERE-dependent signaling pathway. For the simple TATA box promoter, we used the reporter pGL3 (Promega Corp.) plasmids bearing a TATA box promoter with single (ERE) or two EREs (2XERE) (Sathya et al. 2002, Yi et al. 2002a). We also used the pGL3 reporter vector bearing the promoter of the trefoil factor 1, TFF1, or pS2 gene (TFF1-Luc) (Yi et al. 2002a). To simulate ERE-independent signaling, we used an MMP1-Luc reporter plasmid that bears a fragment of the proximal promoter of the matrix metallopeptidase 1, MMP1, gene with single AP1 response element (Webb et al. 1995, Huang et al. 2004, Li et al. 2004) or an RARA-Luc reporter vector derived from the proximal promoter of the retinoic acid receptor $\alpha, R A R A$, gene that contains two GC-boxes (Sun et al. 1998, Huang et al. 2004, Li et al. 2004). In all reporter vectors, promoters drive the expression of the firefly luciferase cDNA as the reporter enzyme. A reporter vector driving the expression of the Renilla luciferase cDNA (Promega) was used to assess transfection efficiency (Yi et al. 2002a, Huang et al. 2004). The ratio of the firefly/Renilla luciferase activities of the cell lysate was determined using a dual luciferase assay kit (Promega Corp.) to obtain the relative luciferase activity.

The Flag M2 antibody, ER $\alpha$-specific H-222, and ER $\beta$-specific antibody D7N were purchased from 
Sigma-Aldrich, Santa Cruz Biotechnology, Inc., and Zymed Laboratories, Inc. (San Francisco, CA, USA) respectively.

$\mathrm{E}_{2}$ and 4-hydroxyl-tamoxifen (4HT) were purchased from Sigma-Aldrich. ICI was obtained from Tocris Biosciences (Ellisville, MO, USA). Restriction and DNAmodifying enzymes were purchased from New England Bio-Labs (Beverly, MA, USA) and Invitrogen Corp.

\section{Transient transfections}

Transient transfections for simulated ERE-dependent and ERE-independent pathways were accomplished as described previously (Yi et al. 2002a, Huang et al. 2004, Li et al. 2004). Transfected cells were treated without or with $10^{-9} \mathrm{M} \mathrm{E}_{2}$ in the absence or presence of $10^{-7} \mathrm{M} 4 \mathrm{HT}$ and/or $10^{-7} \mathrm{M}$ ICI for $24 \mathrm{~h}$ to examine the effects of ligands on ER-mediated transcriptional responses from the ERE-dependent and EREindependent signaling pathways.

\section{In situ $\mathrm{E}_{\mathbf{2}}$ binding assay}

To assess the synthesis and function of GFP fusion ERs in transfected cells, we used an in situ $\mathrm{E}_{2}$ binding assay described previously (Huang et al. 2005b, Li et al. 2008). Briefly, transiently transfected cells in 48-well tissue culture plates were incubated with $10^{-7} \mathrm{M}$ of $\left(2,4,6,7,16,17-{ }_{-3}^{3} \mathrm{H}\right) \quad \mathrm{E}_{2} \quad(118 \mathrm{Ci} / \mathrm{mmol}, \quad \mathrm{NEN} \quad \mathrm{Life}$ Sciences, Boston, MA, USA) in the absence or presence of $10^{-6} \mathrm{M} 4 \mathrm{HT}$ or ICI for $1 \mathrm{~h}$. Cells were then washed extensively with PBS, collected, and radioactivity remaining in cells was measured in a scintillation counter. By the use of in situ ligand binding assay, we estimate that transiently transfected HeLa and MDA-MB-231 cells synthesize about $5 \cdot 5$ - and 4 -fold respectively more ER $\alpha$ compared with MCF-7 cells, a breast adenocarcinoma cell line that endogenously synthesizes ER $\alpha$ (Eckert et al. 1984).

\section{In situ competition for ERE binding assays}

In situ competition for ERE binding assay (Huang et al. 2005b) was used to assess the ability of GFP-ERs to interact with ERE in situ. This assay is based on the interference of a constitutively active potent activator (PPVV)-mediated transcription from a single ERE-driven promoter construct by unliganded or ligand-bound ERs. The extent of interference is then taken as an indication of ER-ERE interactions (Huang et al. 2005b). In brief, cultured cells in 48-well tissue wells were transfected with $125 \mathrm{ng}$ simple TATA box promoter with one ERE and $300 \mathrm{ng}$ expression vector carrying the PPVV cDNA together with $0,75,150$, or $300 \mathrm{ng}$ expression vector containing the cDNA for an
ER. Appropriate amounts of the parent expression vector were added into a given reaction to equalize the total amount of plasmid DNA. A vector bearing the Renilla luciferase cDNA was used as an internal control in the amount of $0.5 \mathrm{ng}$ to normalize the transfection efficiency. Four hours after transfection, cells were maintained in fresh medium supplemented with $10 \%$ CD-FBS in the absence or presence of $10^{-9} \mathrm{M}$ $\mathrm{E}_{2}, 10^{-7} \mathrm{M} 4 \mathrm{HT}$, or ICI for $24 \mathrm{~h}$.

\section{Western blot and electrophoretic mobility shift assay}

Transiently transfected cells with expression vectors in six-well tissue culture plates were maintained for $24 \mathrm{~h}$. Cell extracts $(10 \mu \mathrm{g})$ were subjected to western blot (WB) and electrophoretic mobility shift assay (EMSA) as detailed previously ( $\mathrm{Li}$ et al. 2008, Nott et al. 2009). For WB, proteins were probed with the HRP-conjugated monoclonal Flag antibody (M2-HRP, Sigma-Aldrich). We also used HC-20 and D7N antibodies (Santa Cruz Biotechnology, Inc.) specific to ER $\alpha$ and ER $\beta$ respectively to detect receptor proteins, which were visualized with a second antibody conjugated with HRP. The ECLPlus Western Blotting kit (GE Life Sciences, Piscataway, NJ, USA) was used for the detection of receptor proteins. For EMSA, we used the Flag or a receptorspecific antibody to assess the specificity of ER-ERE interactions. Images from WB and EMSA were analyzed by PhosphorImager (Storm 860, GE Life Sciences) and were quantified with ImageQuant (GE Life Sciences).

We also examined the effects of ER ligands on the detergent extractability and intracellular level of receptor proteins with WB. Cells maintained in sixwell tissue culture plates in 10\% CD-FBS containing media for $24 \mathrm{~h}$ were then transiently transfected for $24 \mathrm{~h}$. Cells were subsequently incubated with fresh medium supplemented with or without $10^{-9} \mathrm{M} \mathrm{E}_{2}$, $10^{-7} \mathrm{M} 4 \mathrm{HT}$, or ICI for $1 \mathrm{~h}$. At the termination of an experiment, cells were collected, pelleted, and subjected to protein extraction using $50 \mu \mathrm{l}$ of a high salt extraction buffer, HSB ( $400 \mathrm{mM} \mathrm{KCl}, 20 \%$ glycerol, $2 \mathrm{mM}$ dithiothreitol (DTT), $1 \mathrm{mM}$ phenylmethylsulphonyl fluoride (PMSF), and 1/14 (v/v) protease inhibitor cocktail, Roche Diagnostics), or RIPA buffer $(0.5 \%$ sodium deoxycholate, $1 \%$ Igepal CA-630, $0 \cdot 1 \%$ SDS, $2 \mathrm{mM}$ DTT, $1 \mathrm{mM}$ PMSF, and $1 / 14(\mathrm{v} / \mathrm{v})$ protease inhibitor cocktail). After the HSB or RIPA extraction, the remaining pellet was also subjected to $50 \mu \mathrm{l} 1 \times$ Laemmli buffer (LB) $(60 \mathrm{mM}$ Tris-Cl, pH $6 \cdot 8,2 \%$ SDS, $10 \%$ glycerol, $5 \% \beta$-mercaptoethanol, and $0.01 \%$ bromophenol blue), to extract insoluble protein aggregates. In addition, we used $100 \mu \mathrm{LB}$ to obtain total cell lysate (TCL) by extracting both soluble and insoluble proteins. Ten micrograms of total protein estimated with Nanodrop 
(ThermoScientific, Wilmington, DE, USA) were subjected to $10-18 \%$ SDS-PAGE.

\section{Chromatin immunoprecipitation assay}

Chromatin immunoprecipitation assay (ChIP) assay was described previously (Huang et al. 2005b). In brief, cells grown in six-well tissue culture plates were co-transfected with expression vector and the reporter vector bearing the TATA box promoter with single ERE. Twenty-four hours after transfection, cells were incubated in fresh medium with or without $10^{-7} \mathrm{M} \mathrm{E}_{2}$, $4 \mathrm{HT}$, or ICI for $1 \mathrm{~h}$. Cells were then subjected to ChIP using the Flag-M2 antibody-conjugated agarose beads (Sigma-Aldrich). The generation of a $366 \mathrm{bp}$ PCR fragment by ChIP indicates the specificity of PCRs. Due to the difficulty of assessing the interaction of ER with EREs of endogenous genes by ChIP in transiently transfected cells, we used recombinant adenovirusinfected MDA-MB-231 cells with which we previously carried out experiments to assess the interactions of $\mathrm{E}_{2}$-ERs with (Huang et al. 2005b), and transcriptional responses from Li et al. (2008), Nott et al. (2009) and Huang et al. (2011), the ERE of TFF1. MDA-MB-231 cells, 100000 cells/well in six-well tissue culture plates, were infected with recombinant adenoviruses in media with $10 \% \mathrm{CD}$-FBS for $48 \mathrm{~h}$. We used recombinant adenovirus bearing $\mathrm{ER} \alpha, \mathrm{ER} \alpha_{\mathrm{EBD}}, \mathrm{ER} \beta$, or $\mathrm{ER} \beta_{\mathrm{EBD}}$ cDNA with sequences encoding a Flag epitope at the amino-terminus at 100, 150, 600, or 900 multiplicity of infection (MOI) respectively together with the parent recombinant adenovirus bearing no cDNA at varying MOI to equalize the total amount of adenovirus, 900 MOI, used for infections. At these MOIs, the synthesis of ERs was comparable ( $\mathrm{Li}$ et al. 2008, Nott et al. 2009, Huang et al. 2011). Forty-eight hours after infections, cells were incubated in fresh medium

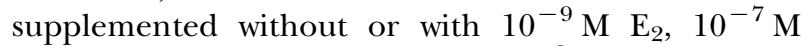
$4 \mathrm{HT}$, or ICI for $1 \mathrm{~h}$. We also used $10^{-8} \mathrm{M}$ ER $\alpha$-selective propyl pyrazole triol agonist or $10^{-8} \mathrm{M}$ ER $\beta$-selective diarylpropionitrile agonist for $1 \mathrm{~h}$. At these concentrations, ligands maximally affected transcriptional responses from reporter constructs induced by ERs or $\mathrm{E}_{2}$-ERs (data not shown). Cells were collected and subjected to ChIP using M2-Flag antibody-conjugated agarose beads (Sigma-Aldrich) as described (Huang et al. 2005b). The production of a $315 \mathrm{bp} \mathrm{PCR} \mathrm{product}$ indicates specific ER-ERE interactions (Supplementary Figure 3A, see section on supplementary data given at the end of this article).

\section{Live cell microscopy and FRAP}

HeLa or MDA-MB-231 cells were grown in $35 \mathrm{~mm}$ glass bottom coverslip dishes (MatTek Corp., Ashland, MA,
USA) in medium containing $10 \%$ CD-FBS without phenol-red for $24 \mathrm{~h}$. Cells were then transiently transfected with $1.5 \mu \mathrm{g}$ of an expression vector bearing the GFP-fusion receptor cDNA. Twenty-four hours after transfections, cells were treated with or without various concentrations $\left(10^{-10}\right.$ to $\left.10^{-7} \mathrm{M}\right)$ of $\mathrm{E}_{2}$ for $1 \mathrm{~h}$ before FRAP analysis. We observed in preliminary studies that $10^{-9} \mathrm{M} \mathrm{E}_{2}$ maximally affected the intracellular mobility of both ER $\alpha$ and ER $\beta$. Based on these findings, we used $10^{-9} \mathrm{M} \mathrm{E}_{2}$ in subsequent FRAP assays. We also treated cells with $10^{-7} \mathrm{M} 4 \mathrm{HT}$ or ICI, a concentration that maximally affected the nuclear mobility of ERs in preliminary experiments. FRAP was performed using an Olympus FV1000 laser scanning confocal microscope containing a full-stage incubator equilibrated to $37^{\circ} \mathrm{C}$ housed at the URMC Confocal and Conventional Microscopy Core. Cells were imaged live using a $60 \times 1.4$ NA oil immersion objective.

Cells were initially examined with differential interference contrast (DIC) to assess the cellular health. To prevent experimental artifacts due to over-expression of GFP-fusion ERs (Stenoien et al. 2001 a,b), cells with low fluorescence intensities (600-1500 arbitrary fluorescence unit) were selected for FRAP analysis. Photo-bleaching was accomplished using a tunnel region of interest (ROI) of the FRAP module. A tunnel ROI as a $9 \times 9$ pixel area $\left(4.468 \mu \mathrm{m}^{2}\right)$ was used for all photo-bleaching experiments. It should be noted that the FRAP results were independent of the shape of ROI, as we obtained similar results from stripe bleaching in preliminary experiments (data not shown). A single $\mathrm{z}$ plane was bleached with the SIM scanner capabilities using the $405 \mathrm{nM}$ laser set to $30 \%$ power for $0.2 \mathrm{~s}$ and simultaneously imaged in freerun $(\sim 0.25 \mathrm{~ms}$ intervals $)$ mode.

FRAP analysis was carried out with FV1000 Olympus post-processing software. Briefly, frames of the timelapse data were moved to the point of photo-bleaching and graphs were obtained for the bleached ROI. Another ROI at a size and fluorescence intensity that corresponded to those of the experimental ROI before photo-bleaching within the same cell was used as the control to assess the background and alterations in total cellular fluorescence due to photo-bleaching (Supplementary Figure 1, see section on supplementary data given at the end of this article). All data were exported to Excel for further analysis. The fluorescence intensity of the control ROI throughout the post-bleach period was used to normalize the recovery of bleached ROI by dividing the fluorescence value of the bleached ROI with that of the control ROI at each time point of imaging. Fluorescence is expressed as relative fluorescence units where zero $(0)$ is the fluorescence after photo-bleaching (time 0 ) and one (1) is the fluorescence of the bleached area reached to pre-bleach levels. Images were exported as Tagged Image File Format (tif) and movie (mov) files. Adobe Photoshop 
(Adobe Systems, Inc.) was used for image analysis. All experiments were carried out using five to seven individual cells per experiment. Results were repeated at least three independent times.

\section{Results}

\section{The synthesis and function of GFP-ERs in HeLa cells}

The interaction of $\mathrm{ER} \alpha$ with permutations of a core palindromic DNA sequence 5'-GGTCAnnnTGACC-3', or ERE as well as ERE half-sites (Kato et al. 1995, Ansari et al. 2012), constitutes the ERE-dependent signaling pathway (Huang et al. 2005a, Zhao et al. 2010). The recognition of an ERE by the ER $\alpha$ dimer is mediated by two zinc-binding motifs in each DBD monomer that fold to form a single functional unit (Schwabe et al. 1993). Distinct residues particularly $\mathrm{Glu}_{203}$ and $\mathrm{Gly}_{204}$ in the DNA recognition helix of the first zinc finger of DBD of the human ER $\alpha$ are critical for DNA sequence discrimination (Schwabe et al. 1993) and also for binding to EREs (DeNardo et al. 2007). We showed that changing $\operatorname{Arg}_{211}$, a conserved amino acid among nuclear hormone receptors critical for receptor-DNA interactions, to $\mathrm{Glu}_{211}$ together with $\mathrm{Ala}_{203}$ and $\mathrm{Ala}_{204}$, which replace $\mathrm{Glu}_{203}$ and $\mathrm{Gly}_{204}$ respectively, generates $\mathrm{ER} \alpha_{\mathrm{EBD}}$ that functions only at the ERE-independent signaling pathway (Nott et al. 2009). Similarly, changing $\mathrm{Glu}_{167}$ and $\mathrm{Gly}_{168}$ in the first zinc finger motif of the DBD of the human ER $\beta$ to Ala also generated ER $\beta_{\mathrm{EBD}}$ that regulates gene transcriptions exclusively through the ERE-independent signaling pathway (Bjornstrom \& Sjoberg 2002, Li et al. 2008).

To examine the effects of ligands on the kinetics of nuclear movement of $\mathrm{ER}_{\mathrm{EBD}}$, we initially assessed the synthesis and biochemical features of GFP fusion receptors in comparison with the wild-type counterparts in transiently transfected HeLa cells derived from an ER-negative cervical carcinoma. Cellular extracts were subjected to $\mathrm{WB}$ using an antibody specific to the Flag epitope present at the amino-terminus of each receptor (Fig. 1A). Results revealed that HeLa cells synthesize GFP-ERs with expected molecular mass. The treatment of cells with a saturating concentration of ${ }^{3} \mathrm{H}-\mathrm{E}_{2}\left(10^{-7} \mathrm{M}\right)$ showed that the radiolabeled $\mathrm{E}_{2}$ is retained in cells synthesizing a GFP-ER as observed in cells synthesizing an ER (Fig. 1B). The treatment of cells with $10^{-6} \mathrm{M} 4 \mathrm{HT}$ or ICI (data not shown) effectively prevented the retention of ${ }^{3} \mathrm{H}-\mathrm{E}_{2}$. Thus, the presence of GFP at the amino-termini of ERs has little effect on the synthesis and the ligand binding abilities of the fusion receptors.

To assess the interaction of GFP-ERs with ERE, we employed EMSA with cellular extracts from transiently transfected HeLa cells (Fig. 1C). Displaying similar
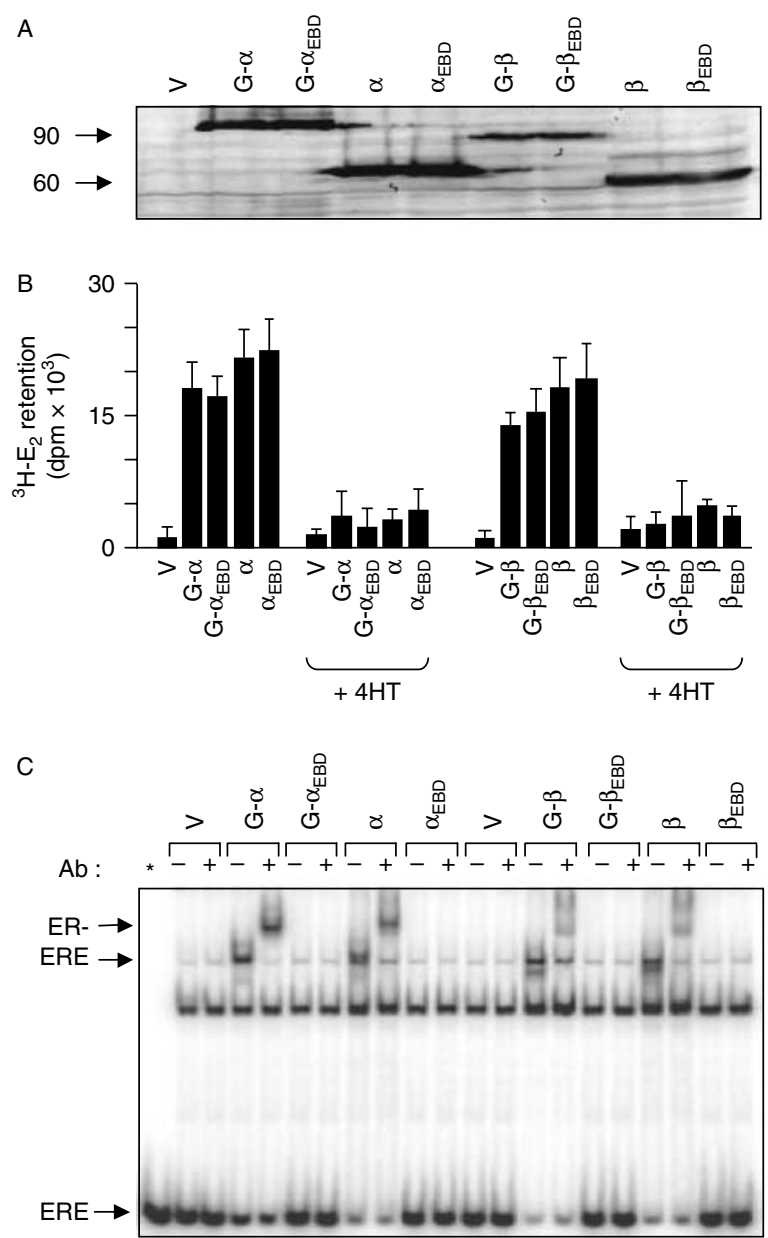

Figure 1 The synthesis of functional GFP-ERs in HeLa cells. (A) The synthesis of ER species. HeLa cells were transiently transfected with an expression vector bearing none (V) or an ER cDNA with or without sequences encoding GFP $(\mathrm{G})$ genetically conjugated to the $5^{\prime}$ of ER coding sequences. Constructs also contain sequences that encode for a Flag epitope present at the amino-terminus of the resulting protein. Cell extracts $(10 \mu \mathrm{g})$ were subjected to WB using a HRP-conjugated monoclonal Flag antibody. Molecular mass in $\mathrm{kDa}$ is indicated. (B) In situ $\mathrm{E}_{2}$ binding assay. Twenty-four hours after transient transfections with an expression vector bearing none $(\mathrm{V})$ or an ER cDNA with $(\mathrm{G})$ or without GFP, HeLa cells were incubated in medium containing $10^{-7} \mathrm{M}$ of ${ }^{3} \mathrm{H}-\mathrm{E}_{2}$ in the absence or presence of $10^{-6} \mathrm{M} \mathrm{4HT}$ $(+4 \mathrm{HT})$ for $1 \mathrm{~h}$. The medium containing the radioactive ${ }^{3} \mathrm{H}-\mathrm{E}_{2}$ was removed and cells were extensively washed with PBS before dislodging. Radioactivity retained in cells was then quantified by scintillation counting. The graph represents the mean \pm S.E.M. of three independent experiments performed in duplicate. (C) The interaction of ERs with ERE in vitro. Cell extracts $(10 \mu \mathrm{g})$ of transfected cells were also subjected to electrophoretic mobility shift assay (EMSA) without $(-)$ or with $(+)$ a receptor-specific antibody $(\mathrm{Ab})$. ERE specifies unbound and ER-ERE denotes ER-bound radiolabeled ERE. Asterisk denotes the free ERE lane. $A$ representative result from a minimum of two independent experiments of WB or EMSA is shown. 
mobilities to those of corresponding parent ERs, the GFP-ER $\alpha$ and GFP-ER $\beta$ retarded the migration of the radiolabeled ERE, whereas GFP-ER $\alpha_{\mathrm{EBD}}$, GFP-ER $\beta_{\mathrm{EBD}}$, or the $\mathrm{ER}_{\mathrm{EBD}}$ showed no binding.

To further ensure that GFP-ERs in response to ligands mimic the effects of the parent ERs on the transcription and GFP-ERs EBD $_{\text {are functional only at }}$ ERE-independent signaling pathways, we used reporter vectors with promoters emulating ERE-dependent and ERE-independent signaling routes (Supplementary Figures 2 and 3, see section on supplementary data given at the end of this article). For the simulated ERE-dependent signaling pathway, we used reporter plasmid bearing two EREs in tandem located upstream of the simple TATA box promoter (2XERE-Luc) or the proximal promoter region derived from the TFF1 gene (TFF1-Luc) bearing an ERE. ER $\alpha$ increased the activity of the reporter enzyme in response to a physiological concentration $\left(10^{-9} \mathrm{M}\right)$ of $\mathrm{E}_{2}$ from both promoters in transfected cells (Supplementary Figure 2A). Although the extent of activations was lower than those induced by $\mathrm{ER} \alpha$, GFP-ER $\alpha$ also increased the enzyme levels in response to $\mathrm{E}_{2}$. The treatment of cells with $10^{-7} \mathrm{M} 4 \mathrm{HT}$ or $10^{-7} \mathrm{M}$ ICI alone had little effect on transcriptional responses mediated by ERs or GFP-ERs. However, 4HT or ICI effectively countered the effect of $\mathrm{E}_{2}$ on the reporter enzyme when cells were co-treated, whereas $E R \alpha_{\text {EBD }}$ or GFP-ER $\alpha_{\text {EBD }}$ did not affect the enzyme activity whether or not cells were exposed to ligands alone or in combination. Similarly, ER $\beta$ or GFP-ER $\beta$, but not the ERE binding-defective counterparts, augmented the activity of the reporter enzyme only in the presence of $E_{2}$, which was blocked by the co-treatment of cells with 4HT or ICI (Supplementary Figure 3A). Thus, GFP-ERs, but not the $\mathrm{ER}_{\mathrm{EBD}}$ with or without GFP, in response to ligands mimic the effects of the parent ERs on the transcription of the reporter enzyme mediated through the ERE-dependent signaling pathway.

We previously showed that MMP1 is a target gene for $\mathrm{E}_{2}$-ER signaling, as ERs in response to $10^{-9} \mathrm{M}$ repress the expression of $M M P 1$ through the ERE-independent signaling pathway (Li et al. 2008, Nott et al. 2009). Simulated systems suggest that the functional interaction of ERs with AP1 bound to an AP1 element provides the basis for the regulation of $M M P 1$ gene promoter in an ER subtype, nature and concentration of ligand, promoter and cell type-dependent manner (Webb et al. 1995, Kushner et al. 2000). Similarly, the interaction of ER with SP1 bound to GC boxes is critical for the ligand-mediated regulation of the RARA gene promoter in reporter assays (Sun et al. 1998, Safe 2001). To ensure that GFP-ERs also mimic the effects of the parent ERs on transcription, an expression vector bearing none or an ER cDNA was transfected into HeLa cells together with MMP1-Luc or the RARA-Luc reporter vector (Supplementary Figure 2B and 3B).
We did not observe a significant effect of $10^{-9} \mathrm{M} \mathrm{E}_{2}$ mediated by ERs with or without GFP on the activity of the reporter enzyme from promoters, which could be due to the promoter composition in reporter constructs. However, $10^{-7}$ M 4 HT mediated transcriptional responses to ERs similarly. ICI at $10^{-7} \mathrm{M}$ also affected the luciferase activity mediated by ER $\alpha$ proteins, but not by ER $\beta$ with or without GFP. Importantly, $\mathrm{ER}_{\mathrm{EBD}}$ mimicked the effects of the parent ERs on transcriptions in response to ligands from reporter vectors emulating ERE-independent signaling pathways. Thus, the presence of GFP at the aminotermini of ERs does not affect the transregulatory functions of the receptors at simulated ERE-independent signaling pathways as well.

\section{Ligand-mediated nuclear mobility of GFP-ERs}

To examine the effects of ligands on nuclear mobility of ERs with or without ERE binding function, transfected HeLa cells were treated with a vehicle (EtOH, 0.01\%) for $1 \mathrm{~h}$ and then subjected to FRAP analysis (Fig. 2). GFP-ER $\alpha$ showed a diffuse distribution throughout the nucleus but it is excluded from nucleoli. After a $0 \cdot 2$-s photo-bleaching, the bleached area equilibrated to pre-bleach levels within $1 \mathrm{~s}$ with a half-maximum recovery rate $(1 / 2 \mathrm{mRR})$ of $<0 \cdot 2 \mathrm{~s}$. On the other hand, the treatment of cells with $10^{-9} \mathrm{M} \mathrm{E}_{2}$ or $10^{-7} \mathrm{M} 4 \mathrm{HT}$ for $1 \mathrm{~h}$ reduced the mobility of the receptor. Fluorescence after photo-bleaching was fully recovered within $40 \mathrm{~s}$ of post-bleaching with a $1 / 2 \mathrm{mRR}$ of about $5 \mathrm{~s}$. By contrast, the treatment of cells with $10^{-7}$ M ICI immobilized GFP-ER $\alpha$ as no fluorescence recovery was observed (up to $15 \mathrm{~min}$, data not shown) in post-bleaching. Consistent with previous studies (Stenoien et al. 2000, 2001 a,b, Sharp et al. 2006, Zwart et al. 2010), our results also demonstrate that GFP-ER $\alpha$ in the unliganded state is a highly mobile molecule and shows different kinetics of mobility in response to ligands.

Similar to the unliganded GFP-ER $\alpha$, GFP-ER $\alpha_{\mathrm{EBD}}$ in the absence of a ligand showed a rapid mobility with $1 / 2 \mathrm{mRR}$ of $<0.2 \mathrm{~s}$ (Fig. 3). Although the treatment of cells with $10^{-9} \mathrm{M} \mathrm{E}_{2}$ or $10^{-7} \mathrm{M} 4 \mathrm{HT}$ for $1 \mathrm{~h}$ slowed the nuclear mobility of GFP-ER $\alpha_{\mathrm{EBD}}$ with a $1 / 2 \mathrm{mRR}$ of about $1 \mathrm{~s}$, the full fluorescence recovery occurred within $10 \mathrm{~s}$ of post-bleaching, much faster kinetics than that observed with $\mathrm{E}_{2^{-}}$or $4 \mathrm{HT}$-liganded $\mathrm{ER} \alpha$. These results indicate that the $\mathrm{E}_{2^{-}}$or $4 \mathrm{HT}$-mediated decrease in the nuclear mobility of $\mathrm{ER} \alpha$ is primarily due to the interaction of the receptor with ERE. ICI, on the other hand, prevented the mobility of GFP-ER $\alpha_{\mathrm{EBD}}$ in the majority of cells (more than 80\%). However, in the remaining cell population, GFP-ER $\alpha_{\mathrm{EBD}}$ in response to ICI showed mobility with varying $1 / 2 \mathrm{mRRs}$ (Supplementary Figure 4, see section on supplementary data given at the end of this article). These results 

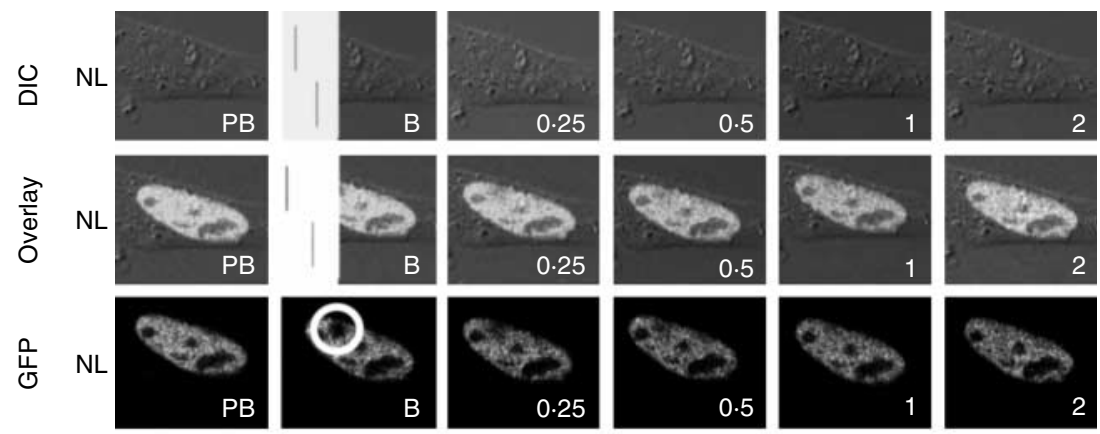

$\mathrm{E}_{2}$
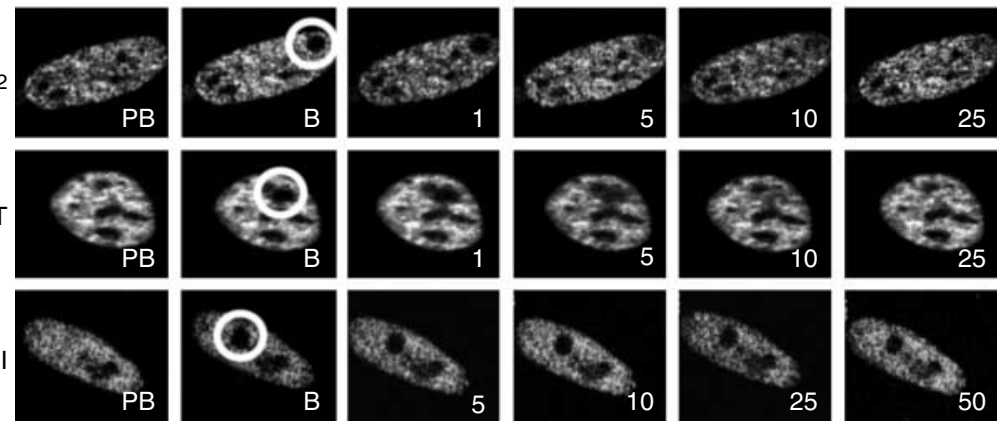

$4 \mathrm{HT}$
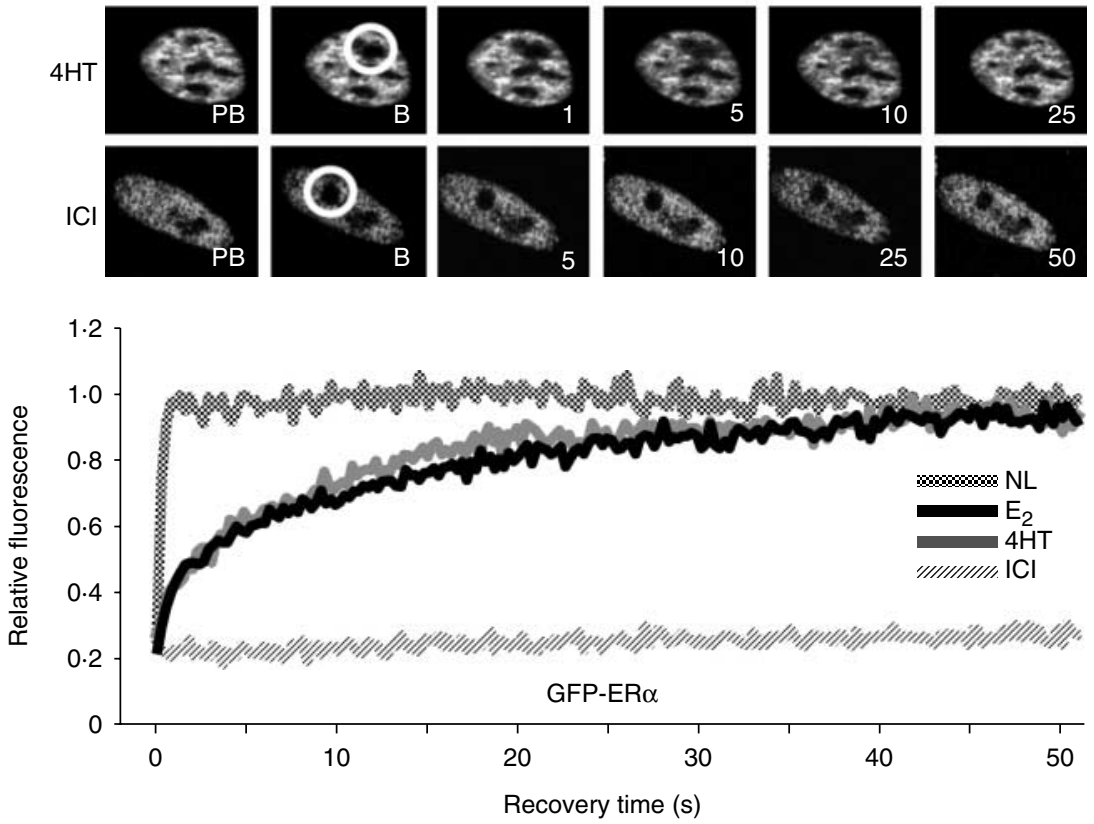

Figure 2 The assessment of nuclear mobility of GFP-ER $\alpha$ by FRAP. HeLa cells transiently transfected with GFP-ER $\alpha$ for $24 \mathrm{~h}$ were treated without (NL) or with $10^{-9} \mathrm{M} \mathrm{E}_{2}$, $10^{-7} \mathrm{M} 4 \mathrm{HT}$, or ICl for $1 \mathrm{~h}$. Cells were then subjected to FRAP analysis. Images were obtained before bleaching (pre-bleach, PB), at bleaching for 0.2 seconds (bleach, B), and at the indicated times in seconds after bleaching. The overlay image (Overlay) was generated with the superimposition of images from DIC and GFP. The time-dependent equilibration of the bleached area (within the white circle) was used to estimate the recovery rate of ER in response to ligands. The recovery rate was based on a control ROI with the size and fluorescence intensity that corresponded to those of the ROI (bleached area) before photo-bleaching within the same cell to normalize the background and alterations in total cellular fluorescence after bleaching (Supplementary Figure 1). The control ROI values obtained throughout the post-bleach period were then used for data normalization. Fluorescence intensity is expressed as the relative fluorescence (RF) where zero (0) is the RF at the photo-bleaching (time 0 ) and one (1) is the fluorescence of the bleached area equilibrated to pre-bleach levels. Graph represents the normalized mean fluorescence recovery of GFP-ER $\alpha$ with or without a ligand in three independent experiments with a minimum of five individual cells per experiment. S.E.M., which was $<15 \%$ of the mean, is not shown for simplicity. 
NL

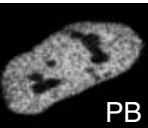

PB

$\mathrm{E}_{2}$

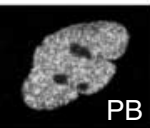

$\mathrm{PB}$

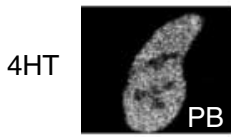

$\mathrm{ICI}$

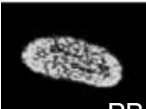

PB
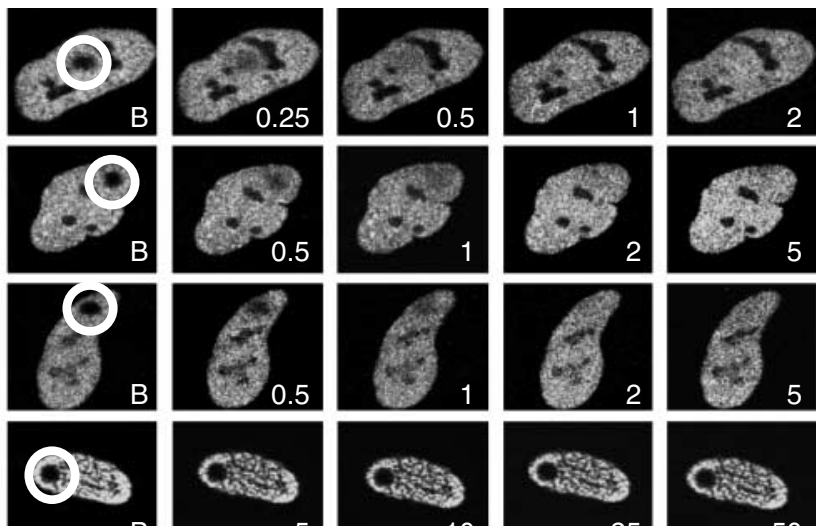

10

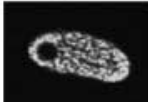

25
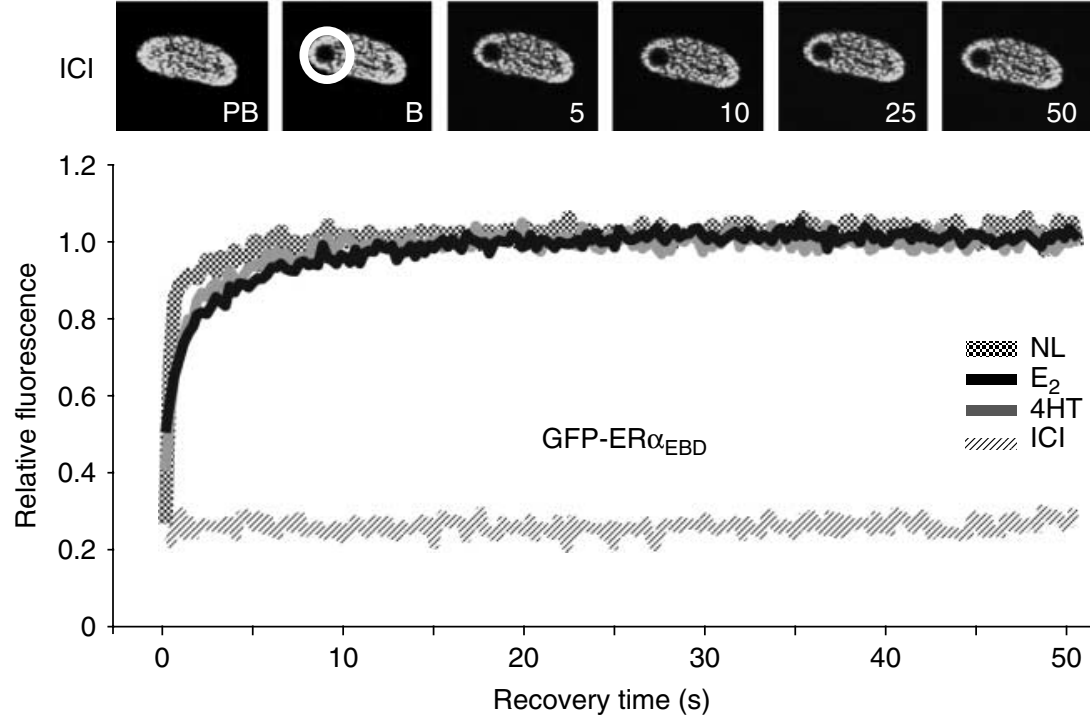

Figure 3 The kinetics of nuclear mobility of GFP-ER $\alpha_{\text {EBD }}$. Transiently transfected HeLa cells were treated without or with ligands for $1 \mathrm{~h}$ and subjected to FRAP analysis as described in the legend of Fig. 2. Graph represents the normalized mean fluorescence recovery of GFP-ER $\alpha_{\mathrm{EBD}}$ in three independent experiments with a minimum of five individual cells per experiment. S.E.M., which was $<15 \%$ of the mean, is not shown for simplicity.

suggest that the DBD of $\mathrm{ER} \alpha$ contributes to but it is not sufficient for the ICI-mediated immobilization of ER $\alpha$.

GFP-ER $\beta$ (Fig. 4A) and GFP-ER $\beta_{\text {EBD }}$ (Fig. 4B) displayed similar patterns of intra-nuclear distribution and kinetics of mobility. In cells synthesizing ER $\beta$ or $\mathrm{ER} \beta_{\mathrm{EBD}}$ in response to the vehicle control, the fluorescence recovery of the region after a $0 \cdot 2$-s photobleaching occurred with a $1 / 2 \mathrm{mRR}$ of about $1 \mathrm{~s}$ that reached pre-bleach fluorescence intensities within $40 \mathrm{~s}$ of post-bleaching. These results, as shown for ER $\beta$ (Damdimopoulos et al. 2008), indicate that the mobilities of the unliganded $\operatorname{ER} \beta$ variants are kinetically slower than the corresponding $\mathrm{ER} \alpha$ species. This was also the case for the $\mathrm{E}_{2^{-}}$or $4 \mathrm{HT}$-liganded $\mathrm{ER} \beta$ proteins. Treatment of cells with $10^{-9} \mathrm{M} \mathrm{E_{2 }}$ or $10^{-7} \mathrm{M} 4 \mathrm{HT}$ decreased the mobility of the receptors that was reflected in $1 / 2 \mathrm{mRRs}$ of about $15 \mathrm{~s}$ with full recoveries occurring within $90 \mathrm{~s}$ after bleaching. Remarkably, both GFP-ER $\beta$ and GFP-ER $\beta_{\mathrm{EBD}}$ in the presence of $10^{-7} \mathrm{M}$ ICI displayed mobilities that were kinetically indistinguishable from those of the $\mathrm{E}_{2^{-}}$or 4HT-bound receptors, in contrast to $\mathrm{ER} \alpha$ species that were stationary in the presence of ICI. Thus, the ability of $\operatorname{ER} \beta$ to bind to ERE is uncoupled from the nuclear mobility of the receptor independent of the nature of ligand.

In addition to alterations in the stability, turnover, and intracellular location of $\mathrm{ER} \alpha$ (Dauvois et al. 1992), ICI rapidly sequesters the receptor to a subcompartment that also involves the nuclear matrix resistant to detergent and salt extractions (Stenoien et al. 2000, 2001 a,b, Long \& Nephew 2006, Lupien et al. 2007). This sequestration appears to be responsible for the immobilization (Stenoien et al. 2000, 2001a,b, Reid et al. 2003) and the absence of interaction with ERE (Reid et al. 2003) of the receptor. By contrast, ICI does not affect the turnover of $\operatorname{ER} \beta$ (Peekhaus et al. 2004, Long et al. 2010). 


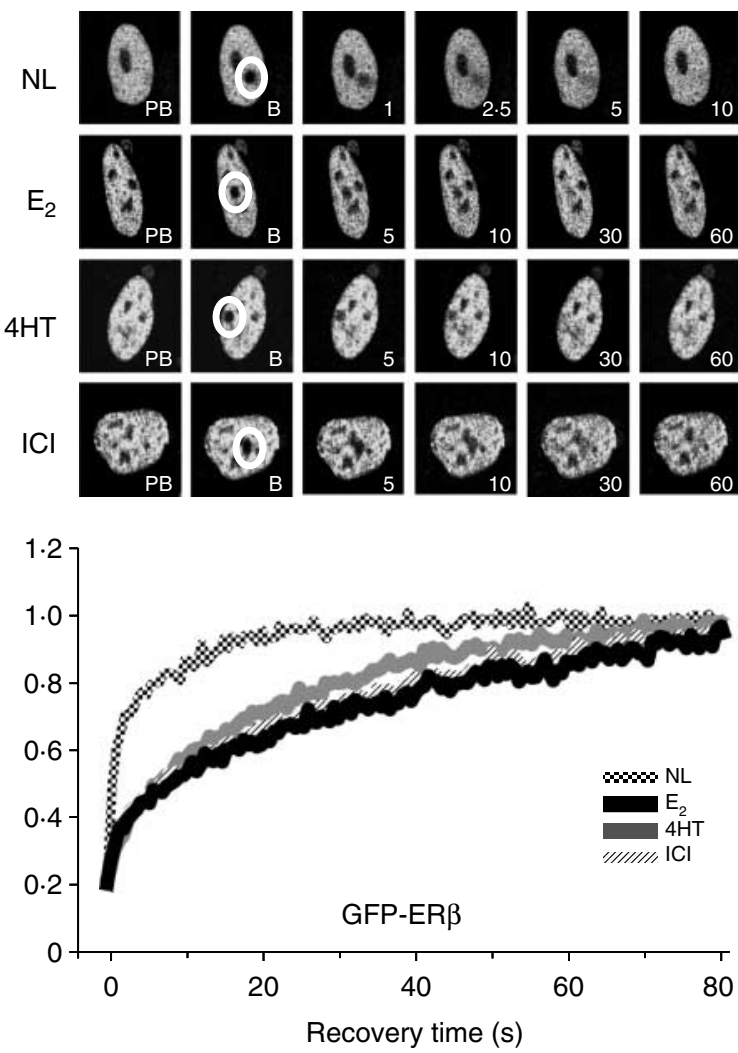

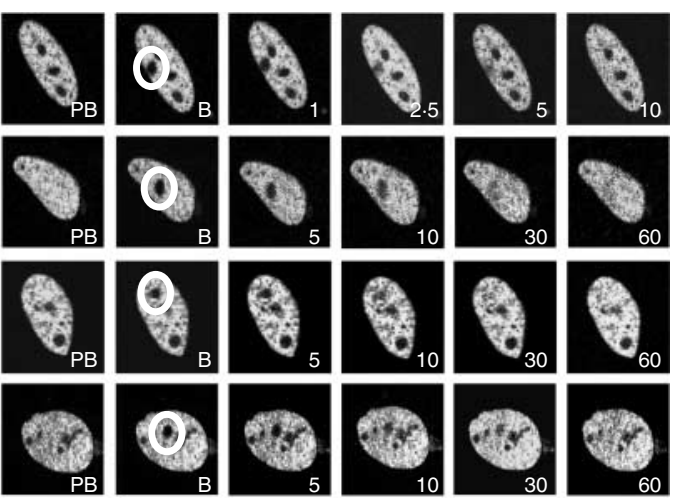

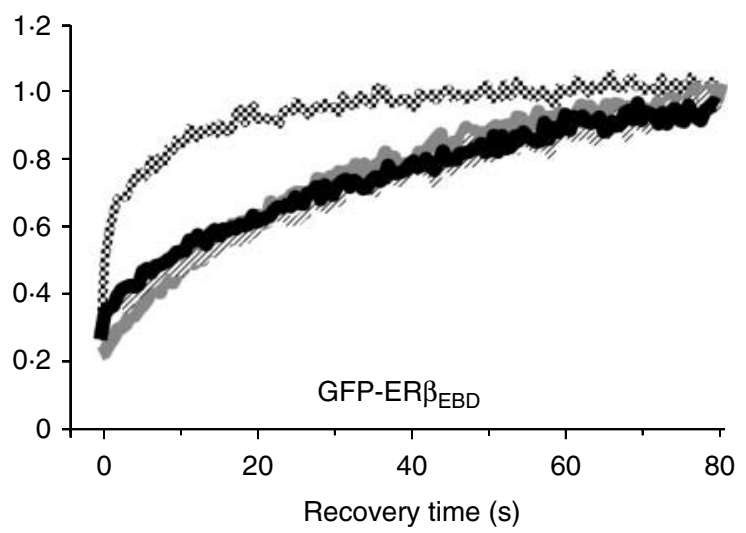

Figure 4 The assessment of the ligand-mediated mobility of GFP-ER $\beta$ (A) and GFP-ER $\beta_{E B D}(B)$ by FRAP. Transient transfection and processing of HeLa cells for FRAP were carried out as described in the legend of Fig. 2. The normalized mean fluorescence recovery of GFP-ER $\beta$ species without $(\mathrm{NL})$ or with a ligand from three independent experiments with a minimum of five individual cells per experiment was graphed without S.E.M., which was $<15 \%$ of the mean.

Indeed, ER $\alpha$ (Fig. 5A) and ER $\beta$ (Fig. 5D) with or without GFP showed different intracellular levels in the presence of ICI. Transiently transfected HeLa cells synthesizing ER $\alpha$ or GFP-ER $\alpha$ for 24 h were treated with or without $10^{-9} \mathrm{M} \mathrm{E}_{2}, 10^{-7} \mathrm{M} 4 \mathrm{HT}$, or ICI for $1 \mathrm{~h}$. Cells were then subjected to protein extractions using a buffer containing high salt (HSB) or detergent (RIPA, data not shown). Extracts $(10 \mu \mathrm{g})$ were then subjected to $\mathrm{WB}$. While $\mathrm{E}_{2}$ or $4 \mathrm{HT}$ had minimal effect on $\mathrm{ER} \alpha$ levels at $1 \mathrm{~h}$ posttreatment, ICI substantially reduced the receptor level in HSB extracts. This was inversely correlated with the detection of a higher receptor amount in ICI, but not $\mathrm{E}_{2}$ or $4 \mathrm{HT}$, treated cell extracts obtained with $1 \times \mathrm{LB}$ to solubilize the insoluble aggregates following HSB extractions. By contrast, WB of TCLs generated with LB to extract both soluble and insoluble protein aggregates revealed that ligands had minimal effects on total receptor levels. This suggests that ICI-mediated rapid immobilization of $E R \alpha$ variants is primarily independent of the receptor degradation.

A rapid sequestration of $\mathrm{ER} \alpha$ with or without GFP by ICI to a nuclear sub-compartment resistant to HSB extraction also predicts that ICI prevents the interaction of GFP-ER $\alpha$ with ERE, as shown previously for ER $\alpha$ (Reid et al. 2003). To address this point, we employed ChIP assay (Fig. 5B). The expression vector bearing none or an ER cDNA was co-transfected with the reporter TATA box promoter vector bearing one ERE into HeLa cells. Cells were treated with or without $10^{-9} \mathrm{E}_{2}, 10^{-7} 4 \mathrm{HT}$, or ICI for $1 \mathrm{~h}$ and processed for ChIP using a Flag antibody. Results revealed that the binding of apoER $\alpha$ to ERE is augmented when cells were treated with $\mathrm{E}_{2}$ or $4 \mathrm{HT}$. ICI effectively prevented ER $\alpha-E R E$ interaction, as there was no PCR product. In clear contrast, $\mathrm{E}_{2}$ or ICI had minimal effects on the binding of ER $\beta$ to ERE (Fig. $5 \mathrm{E}$ ). On the other hand, $4 H T$ enhanced the binding of ER $\beta$ to ERE. As expected, $\mathrm{ER} \alpha_{\mathrm{EBD}}$ or $\mathrm{ER} \beta_{\mathrm{EBD}}$ did not interact with ERE whether or not cells were treated with a ligand.

To correlate the intracellular mobility of GFP-ERs to ERE binding using ChIP with various antibodies directed to different structural domains of fusion receptor with or without Flag epitope proved to be difficult. To circumvent this problem, we used an in situ ERE binding competition assay (Huang et al. 2005b). This assay is based on the ability of ER to compete for 
A

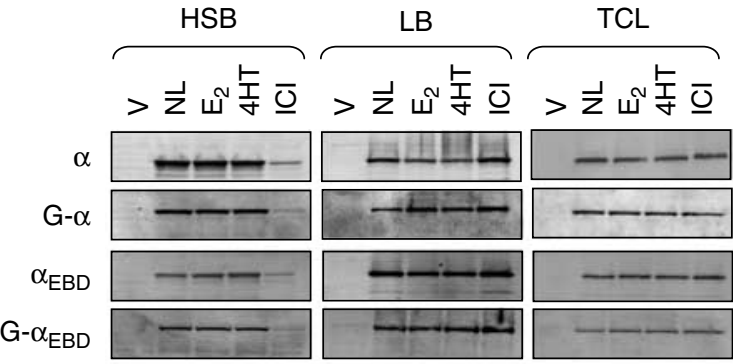

B

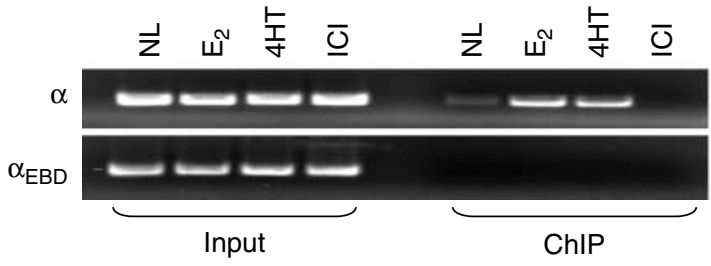

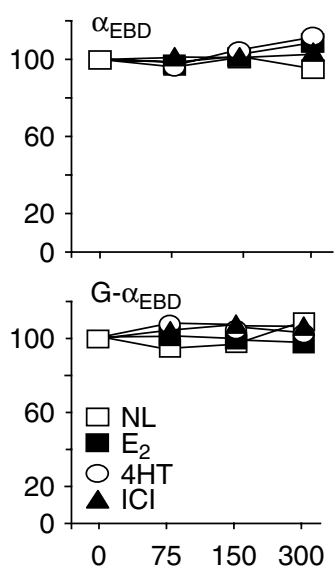

D

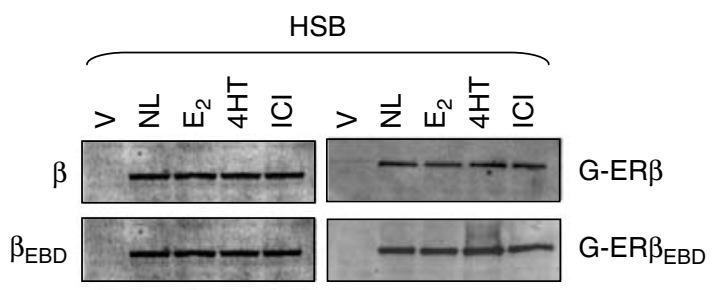

$E$
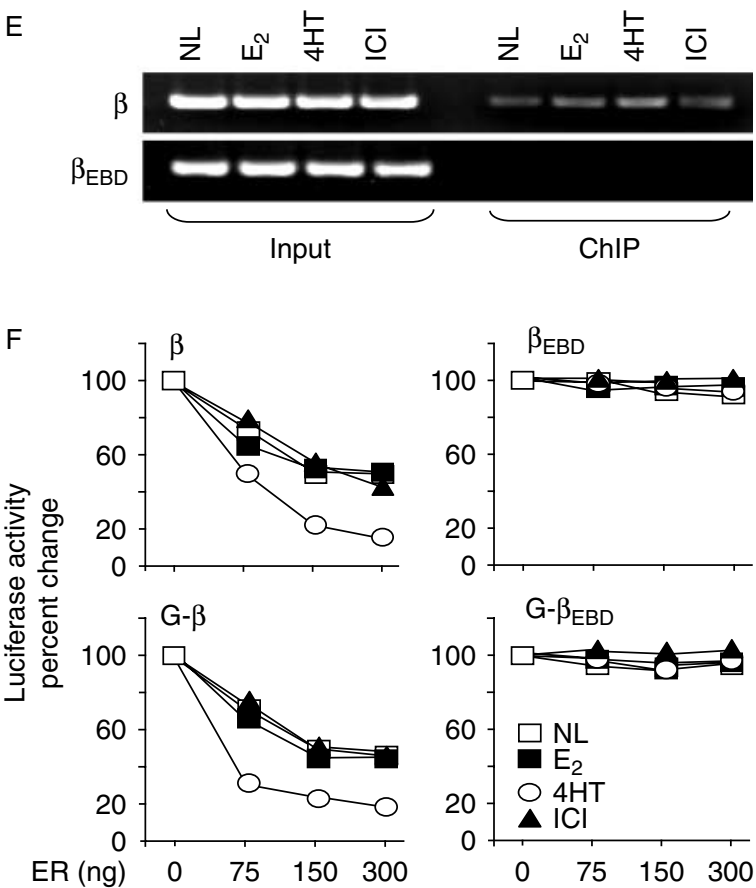

Figure 5 Effects of ligands on protein levels and ERE interactions of ER and ER $E_{E B D}$ with or without GFP. (A) Transiently transfected HeLa cells for $24 \mathrm{~h}$ were incubated with fresh media supplemented with or without $10^{-9} \mathrm{M} \mathrm{E}_{2}, 10^{-7} \mathrm{M} 4 \mathrm{HT}$, or ICl for $1 \mathrm{~h}$. Cells were then collected, washed, re-suspended in $1 \mathrm{ml} \mathrm{PBS}$, and divided into two equal portions. One portion of collected cells was pelleted and subjected to protein extraction using a HSB. The remaining pellet was subjected to $1 \times$ LB to extract insoluble receptor aggregates. The other portion of the suspended cells was pelleted and the pellet was suspended with LB to extract both soluble and insoluble proteins for TCL. $10 \mu \mathrm{g}$ total protein was subjected to $10-18 \%$ SDS-PAGE. Proteins with (G) or without GFP were probed with a receptor specific antibody. All experiments were replicated at least two independent times. (B) ChIP of transiently transfected HeLa cells. Cells co-transfected with expression vector expressing an ER $\alpha$ cDNA and the reporter vector bearing the TATA box promoter with single ERE for $24 \mathrm{~h}$ were treated without (NL) or with $10^{-9} \mathrm{M} \mathrm{E}_{2}, 10^{-7} 4 \mathrm{HT}$, or ICl for $1 \mathrm{~h}$. Cells were then subjected to ChIP using Flag-M2 antibody-conjugated agarose beads. A 366 bp PCR fragment indicates the ER-ERE interactions. Experiments were replicated at least three independent times. (C) The in situ ERE binding competition assay. HeLa cells were co-transfected with $125 \mathrm{ng}$ the TATA box promoter with one ERE that drives the expression of the firefly luciferase cDNA as the reporter enzyme and $300 \mathrm{ng}$ expression plasmid bearing the designer transcription factor, PPVV, without (0 ng ER) or with 75, 150, or 300 ng expression vector bearing an ER cDNA with or without GFP. Cells were then grown in the medium supplemented without (NL) or with $10^{-9} \mathrm{M} \mathrm{E}_{2}$, $10^{-7} \mathrm{M} 4 \mathrm{HT}$, or ICl for $24 \mathrm{~h}$. Normalized luciferase activity is presented as percent change compared with the control (PPVV, $0 \mathrm{ng}$ ER) without ligand, which was set to 100. Graph represents the mean of three independent experiments performed in duplicate; S.E.M., which was $<15 \%$ of the mean, is not shown for simplicity. (D) Transfected HeLa cells with an expression vector bearing none (V) or an ER $\beta$ CDNA were treated without (NL) or with $10^{-9} \mathrm{M} \mathrm{E}_{2}, 10^{-7} \mathrm{M} 4 \mathrm{HT}$, or ICI for $1 \mathrm{~h}$. Cells were collected, pelleted, and subjected to protein extraction using HSB. $10 \mu \mathrm{g}$ total protein was subjected to $10-18 \%$ SDS-PAGE. Proteins were probed with a receptor-specific antibody. The image is from an experiment that was repeated at least three independent times. (E) ChIP assays for in situ interactions of $E R \beta$ and $E R \beta_{\mathrm{EBD}}$ with ERE in HeLa cells were carried out using the M2-Flag antibody-conjugated agarose beads as described for $E R \alpha$ proteins. A representative image from an experiment repeated three independent times is shown. (F) Transient transfections of HeLa cells for the assessment of the binding of ER $\beta$ proteins with $(G)$ or without ERE using the in situ ERE binding competition assay are accomplished as described for ER $\alpha$. The mean of three independent experiments performed in duplicate without the S.E.M., which was $<15 \%$ of the mean, is shown. 
ERE binding with a designer activator, PPVV, that constitutively and potently induces transcription from the TATA box promoter construct bearing single ERE (ERE-TATA) at which ERs have minimal effect on transcription (Huang et al. 2005b). Thereby, interference of activator-mediated transcription by unliganded or liganded ERs is taken as an indication of ER-ERE interaction.

The reporter ERE-TATA plasmid was co-transfected with an expression vector encoding the PPVV cDNA into HeLa cells in the absence (0) or presence of varying amounts $(75,150$, and $300 \mathrm{ng} /$ well) of an expression vector bearing an ER cDNA (Fig. 5C). Cells were then treated with or without $10^{-9} \mathrm{M} \mathrm{E}_{2}$, $10^{-7} \mathrm{M} 4 \mathrm{HT}$, or ICI for $24 \mathrm{~h}$. As PPVV does not bind to a ligand and consequently ligands do not affect the transregulatory potential of PPVV (Huang et al. $2005 b)$, the normalized luciferase activity mediated by PPVV alone in the absence of a ligand was set to $100 \%$. Alterations in the reporter enzyme activity as a result of a co-transfected ER in the absence or presence of a ligand are depicted as percentage change compared with the activity induced by PPVV alone (0 ng ER). Similar to results obtained with ChIP assay, $\mathrm{E}_{2}$ or $4 \mathrm{HT}$ increased the ability of ER $\alpha$ or GFP-ER $\alpha$ to interact with ERE reflected in a further repression of the PPVV-induced luciferase activity by the unliganded ER $\alpha$ with or without GFP. The treatment of cells with ICI, on the other hand, had no effect on enzyme levels induced by PPVV. This suggests that ICI prevents the binding of ER $\alpha$ or GFP-ER $\alpha$ to ERE. The effect of ER $\alpha$ in the absence or presence of ligand on PPVV-mediated enzyme activity requires ERE interactions as ER $\alpha_{\mathrm{EBD}}$ or GFP-ER $\alpha_{\mathrm{EBD}}$ did not alter enzyme levels whether or not cells were exposed to a ligand. Thus, the decrease in the nuclear mobility of $\mathrm{ER} \alpha$ mediated by $\mathrm{E}_{2}$ or $4 \mathrm{HT}$ is dependent upon the ability of the receptor to interact with ERE, whereas ICI sequesters the majority of the receptor to and immobilizes at a nuclear sub-compartment, thereby preventing ER $\alpha-\mathrm{ERE}$ interactions.

In clear contrast to $\mathrm{ER} \alpha$, the short-term treatment $(1 \mathrm{~h})$ of cells with ICI as $\mathrm{E}_{2}$ or $4 \mathrm{HT}$ did not affect intracellular levels of $E R \beta$ or $E R \beta_{\mathrm{EBD}}$ with or without GFP (Fig. 5D). The absence of an effect of ICI, as $\mathrm{E}_{2}$ or $4 \mathrm{HT}$, on levels and mobilities of ER $\beta$ proteins also predicts that ICI does not alter ER $\beta$-ERE interactions in situ. Indeed, ChIP (Fig. 5E) or the in situ ERE binding competition assay (Fig. $5 \mathrm{~F}$ ) revealed that $\mathrm{E}_{2}$ or ICI did not affect the binding of ER $\beta$ or GFP-ER $\beta$ to ERE, whereas $4 \mathrm{HT}$ increased ER $\beta$-ERE interactions. As expected, the ER $\beta_{\mathrm{EBD}}$ with or without GFP did not bind to ERE. These findings imply that the ligandmediated nuclear mobility of ER $\beta$ is independent of nature of ligands and the ability of ER $\beta$ to bind to ERE.

\section{Effects of ligands on transregulatory function and nuclear mobility of GFP-ERs in MDA-MB-231 cells}

To examine whether or not the effects of ligands on the nuclear mobilities of ERs are cell type specific, we also used ER-negative MDA-MB-231 cells derived from a breast adenocarcinoma. Exogenously introduced ER $\alpha$ or ER $\beta$ in MDA-MB-231 cells modulates genomic and cellular responses in the presence of $\mathrm{E}_{2}$ (Garcia et al. 1992, Zajchowski et al. 1993, Lazennec et al. 2001, Li et al. 2008, Nott et al. 2009, Huang et al. 2011). In this cell line, $4 \mathrm{HT}$ acts as an ER $\alpha$ subtype-specific agonist by mimicking the effects of $\mathrm{E}_{2}$ on cellular responses when mediated by the ERE-dependent signaling pathway, whereas ICI is an antagonist for both ER subtypes (Bentrem et al. 2001, Tonetti et al. 2003). The $\mathrm{ER}_{\mathrm{EBD}}$ do not interact with the ERE sequence of the estrogenresponsive TFF1 gene with or without ligands, while ligands differentially alter the parent ER-ERE interactions (Supplementary Figure 5A, see section on supplementary data given at the end of this article). Moreover, providing evidence for a functional EREindependent signaling pathway, we recently showed that the DNA binding-defective ERs participate in the finetuning of phenotypic features of MDA-MB-231 cells by regulating the expression of a subset of estrogen-responsive genes (Li et al. 2008, Nott et al. 2009).

Transient transfections of MDA-MB-231 cells with heterologous reporter vectors emulating ERE-dependent and ERE-independent signaling pathways revealed that the GFP fusion-ERs mimic the abilities of the parent receptors to regulate transcription in response to ligands (Supplementary Figures 5 and 6, see section on supplementary data given at the end of this article).

The nuclear motilities of GFP-ER $\alpha$ with or without ligands in MDA-MB-231 cells (Fig. 6) showed patterns indistinguishable from those observed in HeLa cells. However, the rate and the time of the total recovery of $\mathrm{ER} \alpha$ variants in response to $\mathrm{E}_{2}$ or $4 \mathrm{HT}$ were about twofold slower than those of the receptor synthesized in HeLa cells. The $1 / 2 \mathrm{mRR}$ of the unliganded GFP-ER $\alpha$ or GFP-ER $\alpha_{\text {EBD }}$ was $<0 \cdot 2 \mathrm{~s}$ with a total recovery within $5 \mathrm{~s}$ after photo-bleaching. The treatment of cells with $10^{-9} \mathrm{M} \mathrm{E}_{2}$ or $10^{-7} \mathrm{M} 4 \mathrm{HT}$ in cells synthesizing GFP-ER $\alpha$ increased the $1 / 2 \mathrm{mRR}$ of the bleached region to about 11 and $9 \mathrm{~s}$ respectively with a full fluorescence recovery occurring within $60 \mathrm{~s}$ of post-bleaching. ICI at $10^{-7} \mathrm{M}$ effectively halted the fluorescence recovery of GFP-ER $\alpha$. As observed in HeLa cells, ICI also prevented the recovery of the bleached region in the majority of cells (more than $80 \%$ ) synthesizing GFP-ER $\alpha_{\mathrm{EBD}}$, while the rate of fluorescence recovery vastly varied in individual cells in the remaining population (data not shown). These findings support our conclusion that the DBD contributes to ICI-mediated immobilization of $\mathrm{ER} \alpha$. On the other hand, the unliganded GFP-ER $\alpha_{\mathrm{EBD}}$ 


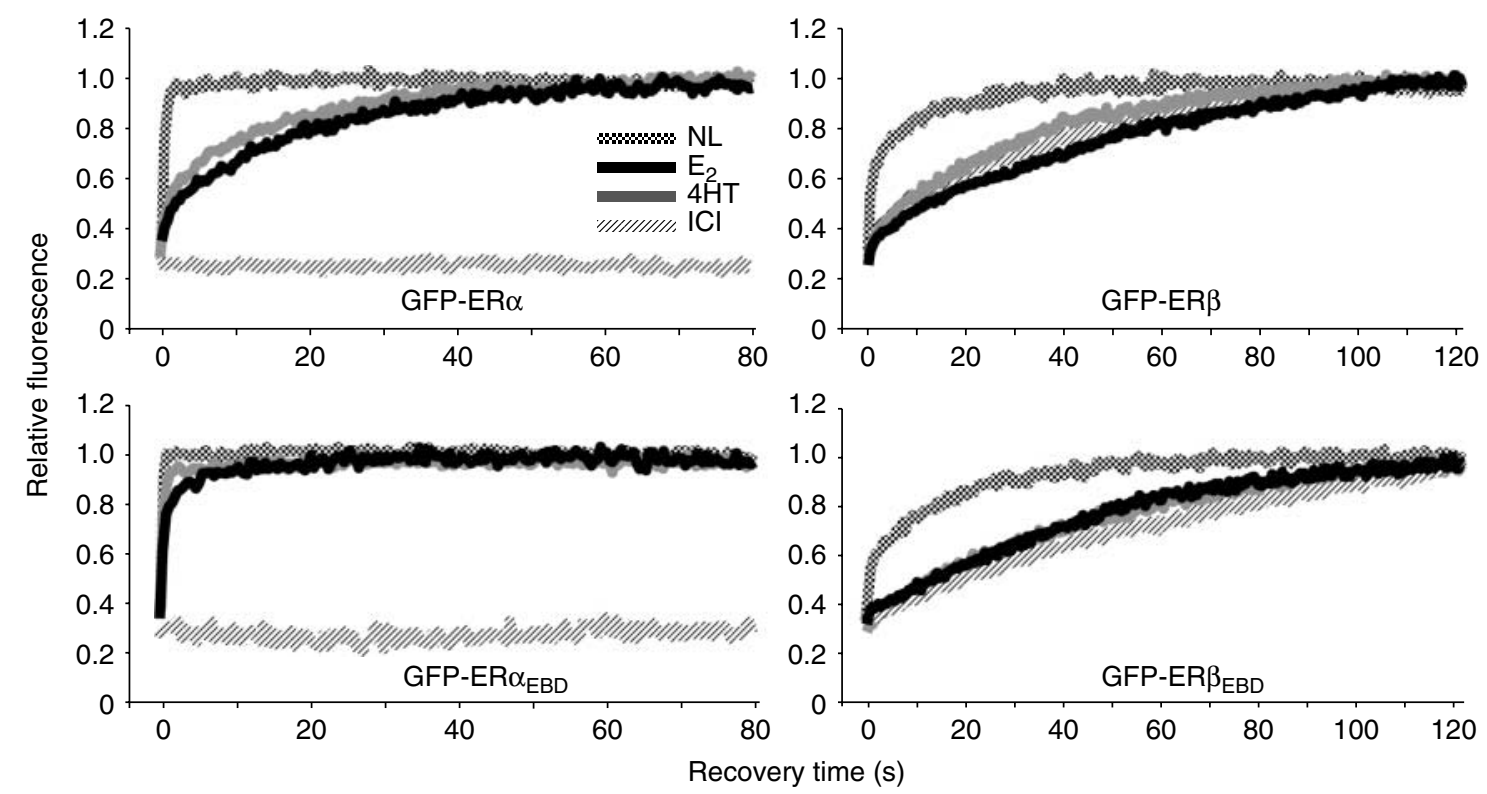

Figure 6 The effects of ligands on the nuclear mobility of GFP fusion ER proteins in MDA-MB-231 cells. Transiently transfected cells for $24 \mathrm{~h}$ were incubated in the absence $(\mathrm{NL})$ or presence of $10^{-9} \mathrm{M} \mathrm{E}_{2}, 10^{-7} \mathrm{M} 4 \mathrm{HT}$, or ICI for $1 \mathrm{~h}$ and subjected to FRAP analysis as described in the legend of Fig. 2. Graph represents the normalized mean fluorescence recovery of GFP-ER with or without a ligand in three independent experiments with a minimum of five individual cells per experiment. The S.E.M., which was $<15 \%$ of the mean, is not shown.

showed a very rapid recovery with a $1 / 2 \mathrm{mRR}$ of $<0 \cdot 2 \mathrm{~s}$ with a full recovery occurring within $1 \mathrm{~s}$. This was similar to the rate of recovery of GFP-ER $\alpha_{\mathrm{EBD}}$ in cells exposed to $\mathrm{E}_{2}$ or $4 \mathrm{HT}$ with the fluorescence equilibration occurring within $10 \mathrm{~s}$ of post-bleaching. Thus, the $\mathrm{E}_{2^{-}}$or $4 \mathrm{HT}$-mediated decrease in the nuclear mobility of $\mathrm{ER} \alpha$ is dependent upon the ability of the receptor to interact with ERE and is independent of cell type.

The fluorescence recovery of GFP-ER $\beta$ in the absence or presence of a ligand was kinetically similar to that of GFP-ER $\beta_{\mathrm{EBD}}$ in MDA-MB-231 cells and mirrored those observed in HeLa cells wherein the overall rate of recovery was faster for both receptor species. In the absence of ligand, the bleached region synthesizing $\mathrm{ER} \beta$ or $\mathrm{ER} \beta_{\mathrm{EBD}}$ recovered within $40 \mathrm{~s}$ of post-bleaching with a $1 / 2 \mathrm{mRR}$ of about $1 \mathrm{~s}$. Treatment of cells with $\mathrm{E}_{2}$, $4 \mathrm{HT}$, or ICI slowed the rate of fluorescence recovery to about $25 \mathrm{~s}$ with a full recovery within $120 \mathrm{~s}$ postbleaching. Thus, the ability of ER $\beta$ to bind to ERE is not reflected in the nuclear mobility of the receptor, which is also independent of the nature of ligand and cell context.

\section{Structural domains responsible for ER subtype- specific nuclear mobility}

The amino- and carboxyl-termini of ERs functionally differ (Cowley \& Parker 1999, Hall \& McDonnell 1999, Yi et al. 2002a, Huang et al. 2005b). To examine the roles of structural termini on the nuclear mobility of ERs, we used GFP fusion ER chimera proteins. In $E R \alpha_{N} \beta_{C}$ and $E R \beta_{N} \alpha_{C}$, the entire amino-termini of the receptors are genetically interchanged (Yi et al. 2002a). We found in transiently transfected HeLa cells that the fluorescence recoveries of $E R \alpha_{N} \beta_{C}$ with or without a functional ERE binding (data not shown) were kinetically similar to those observed with ER $\beta$ s in the absence or presence of ligands (Fig. 7). Conversely, $E R \beta_{N} \alpha_{C}$ or the ERE binding-defective $E R \beta_{N} \alpha_{C}$ mimicked the nuclear mobilities of ER $\alpha$ proteins with or without a ligand (data not shown). These results indicate that the carboxyl-termini are the structural basis for the difference in the nuclear mobility of ER subtypes in the absence or presence of a ligand.

Distinct conformational features of ER carboxyltermini induced by a ligand determine the formation of a functional co-regulator interacting surface responsible for AF2 of the receptors. We also addressed whether the changing of the critical residues that prevent AF2 affects the subtype-specific nuclear mobility of ERs in response to ligands. To examine this issue, we used the GFP-fusion ERs with abrogated AF2 $\left(\mathrm{ER}_{\mathrm{AF} 2}\right)$. In transiently transfected HeLa cells, the nuclear mobility of the unliganded, $\mathrm{E}_{2^{-}}$or $4 \mathrm{HT}$-bound GFP-ER $\alpha_{\mathrm{AF} 2}$ showed kinetics of mobility (Fig. 8A) similar to that of $\mathrm{ER} \alpha$ (Fig. 2). GFP-ER $\alpha_{\mathrm{AF} 2}$ was also mobile when ICI was present. This suggests that the absence of AF2 renders $\mathrm{ER} \alpha$ mobile when ICI is present. ICI, as $\mathrm{E}_{2}$ or $4 \mathrm{HT}$, also had minimal effects on the FRAP of the ERE binding-defective receptor with 

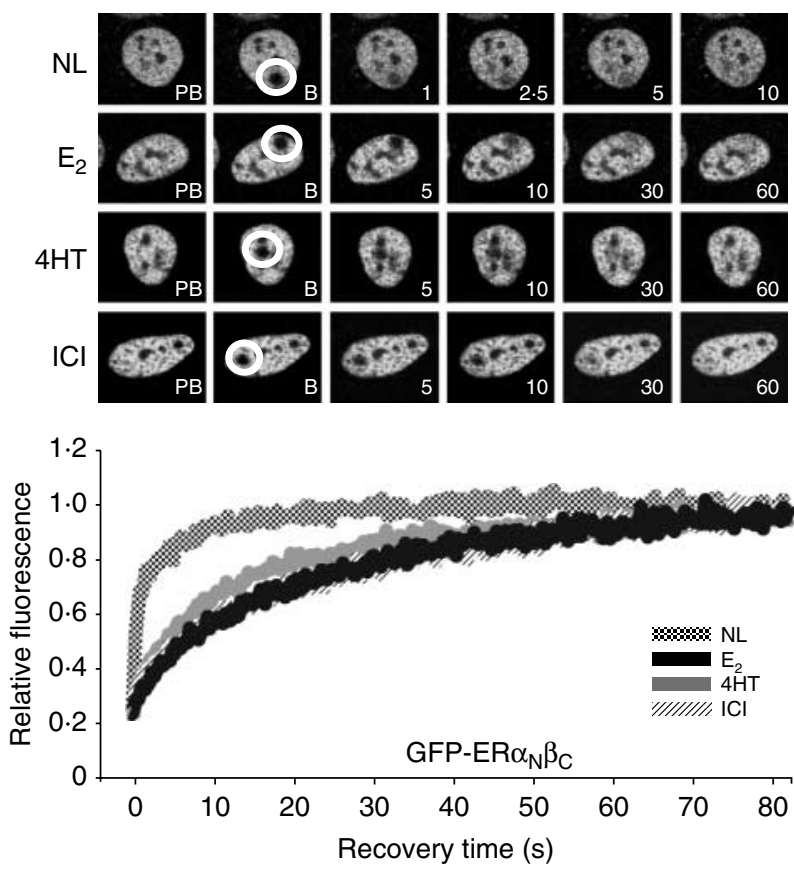

Figure 7 The nuclear mobility of the chimeric $E R \alpha_{N} \beta_{C}$ in HeLa cells. Transiently transfected cells for $24 \mathrm{~h}$ were incubated in the absence (NL) or presence of $10^{-9} \mathrm{M} \mathrm{E}_{2}, 10^{-7} \mathrm{M} 4 \mathrm{HT}$, or ICl for $1 \mathrm{~h}$. Cells were subjected to FRAP analysis as described in the legend of Fig. 2. Graph represents the normalized mean fluorescence recovery of GFP-ER $\alpha_{N} \beta_{C}$ from three independent experiments with a minimum of five individual cells per experiment. S.E.M., which was $<15 \%$ of the mean, is not shown for simplicity.

abrogated AF2, GFP-ER $\alpha_{\mathrm{EBD}+\mathrm{AF2}}$ (Fig. 8B). $\mathrm{ER} \alpha_{\mathrm{AF} 2}$ or $\mathrm{ER} \alpha_{\mathrm{EBD}}+\mathrm{AF} 2$ without or with GFP was HSB extractable (Fig. 8C). Moreover, ICI-ER $\alpha_{\mathrm{AF} 2}$ gained the ability to interact with ERE in situ (Fig. 8D) in stark contrast to ICI-ER $\alpha$, which was immobile due to the sequestration to a nuclear sub-compartment resistant to HSB extraction. However, ER $\alpha_{\mathrm{AF} 2}$ with or without GFP was transcriptionally inactive when cells were treated with ICI, $\mathrm{E}_{2}$, or $4 \mathrm{HT}$ (Fig. 8E). Thus, it appears that the ligand-mediated nuclear mobility and the ability to interact with and to induce transcription from target sites of $\mathrm{ER} \alpha$ are discernable. A much faster kinetics of mobility of $\mathrm{ER} \alpha_{\mathrm{EBD}}$ compared with that of $\mathrm{ER} \alpha$ in response to $\mathrm{E}_{2}$ or $4 \mathrm{HT}$ also indicate that the mobility of $\mathrm{ER} \alpha$ at the ERE-independent signaling pathway contributes fractionally to the overall nuclear mobility of the receptor.

The prevention of AF2 did not alter the pattern or the kinetic of mobility of the GFP-ER $\beta_{\mathrm{AF} 2}$ mutant compared with that of the GFP-ER $\beta$ in the absence or presence of ligands (Fig. 9A). The pattern of fluorescence recovery of GFP-ER $\beta_{\mathrm{EBD}}+\mathrm{AF} 2$ was also similar to that of GFP-ER $\beta_{\mathrm{AF} 2}$ (Fig. 9B). Interestingly, however, the nuclear movement of GFP-ER $\beta_{\mathrm{EBD}+\mathrm{AF} 2}$ occurred at slower kinetics than GFP-ER $\beta_{\mathrm{EBD}}$ or GFP-ER $\beta_{\mathrm{AF} 2}$ in the absence or presence of ligands. The fluorescence level of the bleached region in cells synthesizing $\mathrm{ER} \beta_{\mathrm{EBD}}+\mathrm{AF} 2$ in the absence of ligand reached pre-bleach levels with $\mathrm{a} 1 / 2 \mathrm{mRR}$ of about $6 \mathrm{~s}$, whereas the fluorescence recovery in cells synthesizing GFP-ER $\beta_{\mathrm{EBD}}$ or GFP-ER $\beta_{\mathrm{AF} 2}$ was about $1 \mathrm{~s}$. The treatment of cells with $\mathrm{E}_{2}, 4 \mathrm{HT}$, or ICI decreased the mobility of $\mathrm{ER} \beta_{\mathrm{EBD}}+\mathrm{AF} 2$ similarly, reflected in a $1 / 2 \mathrm{mRR}$ of about $20 \mathrm{~s}$ in comparison with liganded GFP-ER $\beta_{\mathrm{EBD}}$ that showed recovery rates of about $15 \mathrm{~s}$. This suggests that integrated effects of the DBD and the LBD of ER $\beta$ are important for the mobility characteristics of ER $\beta$.

Ligands did not affect the intracellular levels of the receptor species (Fig. 9C). The treatment of cells with or without a ligand did not alter the ability of $\mathrm{ER} \beta_{\mathrm{AF} 2}$ or GFP-ER $\beta_{\mathrm{AF} 2}$ to interact with ERE in situ (Fig. 9D), despite the fact that the receptors were transcriptionally silent at simulated ERE-dependent and ERE-independent signaling pathways (Fig. 9E). Showing similar intracellular levels in the absence or presence of a ligand (Fig. 9C), $\mathrm{ER} \beta_{\mathrm{EBD}+\mathrm{AF} 2}$ with or without GFP did not bind to ERE (Fig. 9D) nor did it modulate the reporter enzyme levels whether or not cells were treated with a ligand (Fig. 9E).

Thus, the nuclear mobility of ER $\beta$ is independent from the nature of ligand and from the ability of the receptor to interact with target sites. These results imply that ER $\beta$ mediates gene transcription through the ERE-dependent and ERE-independent signaling pathways with similar kinetics.

\section{Discussion}

ERs are highly mobile proteins partitioned dynamically between the nucleoplasm and target sites on the chromatin that constitute the ERE-dependent and ERE-independent signaling pathways. We here assessed the relative contribution of ER mobility at the EREindependent signaling pathway to the overall mobility of receptors to gain insights into mechanisms of action.

Our observations revealed several distinct features of ER $\beta$ mobility compared with ER $\alpha$. These are as follows: i) ER $\beta$ mobility with or without ligands is slower than $\mathrm{ER} \alpha$ mobility. ii) The interaction of ER $\beta$ with ERE is augmented with $4 \mathrm{HT}$ but not with $\mathrm{E}_{2}$ or ICI, whereas $\mathrm{E}_{2}$ and 4HT enhance and ICI prevents ER $\alpha-\mathrm{ERE}$ interactions. iii) ICI does not sequester ER $\beta$ with or without ERE binding and/or AF2 functions to a nuclear sub-compartment, whereas the sequestration of ER $\alpha$ is dependent on AF2. iv) The ability of ER $\beta$ to interact with and to induce transcription from target sites is largely uncoupled from the receptor mobility. v) Cooperation between DBD and LBD contributes to ER $\beta$ motility. Based on these observations, we conclude that while ICI immobilizes $\mathrm{ER} \alpha$ to a sub-nuclear 

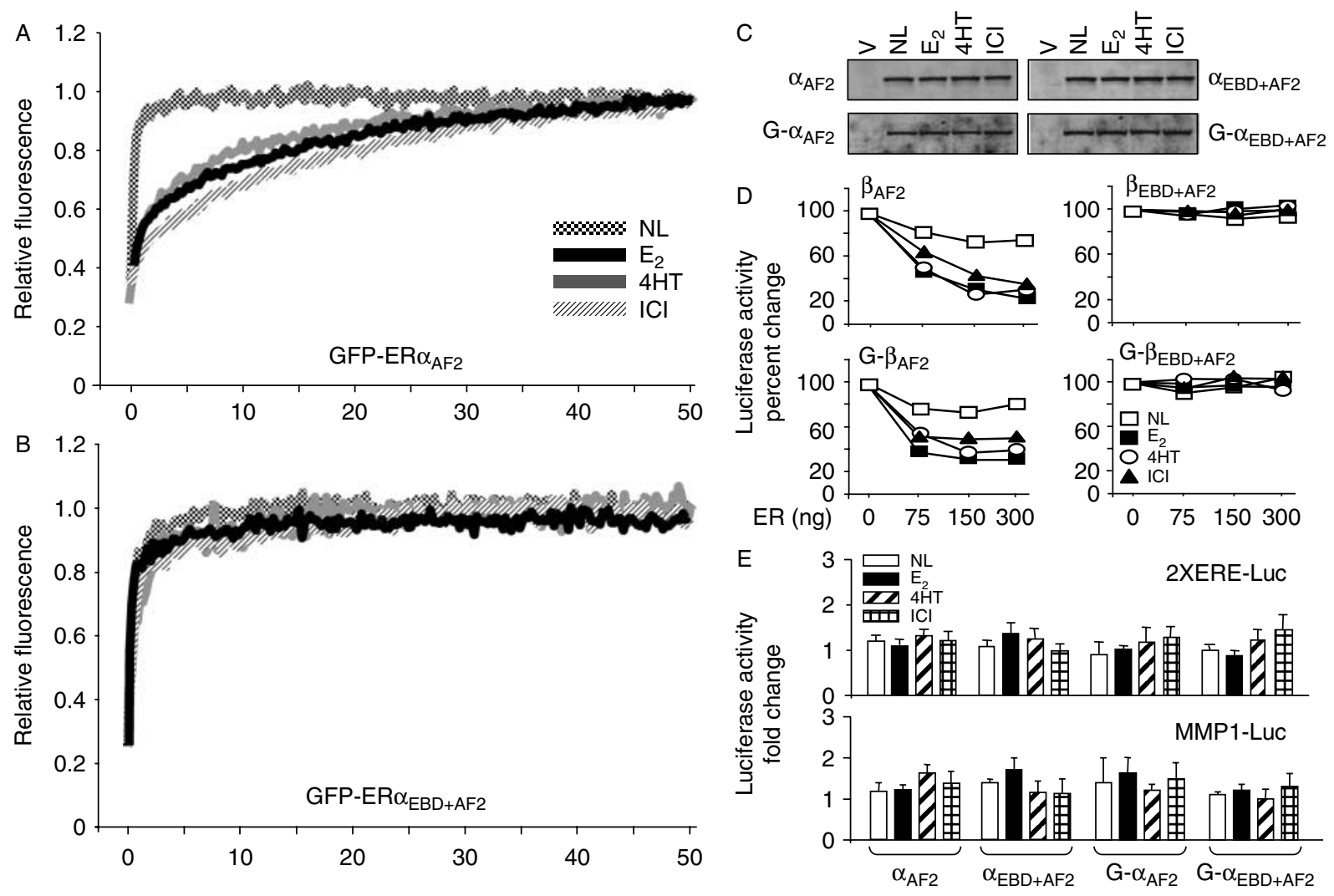

Figure 8 The nuclear mobility of the GFP-ER $\alpha_{A F 2}$ with GFP-ER $\alpha_{E B D}+A F 2$ in HeLa cells. Transiently transfected cells for $24 \mathrm{~h}$ were incubated in the absence (NL) or presence of $10^{-9} \mathrm{M} \mathrm{E}_{2}, 10^{-7} \mathrm{M} 4 \mathrm{HT}$, or ICl for $1 \mathrm{~h}$. Cells synthesizing GFP-ER $\alpha_{\mathrm{AF} 2}(\mathrm{~A})$ or GFP-ER $\alpha_{E B D}+A F 2$ (B) were subjected to FRAP analysis as described in the legend of Fig. 2. Graphs represent the normalized mean fluorescence recovery of $E R \alpha$ proteins from three independent experiments with a minimum of five individual cells per experiment. The S.E.M., which was $<15 \%$ of the mean, is not shown for simplicity. (C) Intracellular levels of ER $\alpha_{A F 2}$ and ER $\alpha_{E B D+A F 2}$ with (G) or without in transiently transfected in HeLa cells for $24 \mathrm{~h}$. Cells were then treated in the absence or presence of $10^{-9} \mathrm{M} \mathrm{E}_{2}$, $10^{-7} \mathrm{M} 4 \mathrm{HT}$, or ICl for $1 \mathrm{~h}$. Cells were collected, pelleted, and subjected to protein extraction using HSB. $10 \mu \mathrm{g}$ total protein was subjected to 10-18\% SDS-PAGE. Proteins were probed with a receptor-specific antibody. Experiments were repeated two independent times. (D) Assessing the effects of ligands on in situ ERE binding abilities of $E R \alpha_{A F 2}$ and $E R \alpha_{E B D}+A F 2$ with (G) or without GFP. Transiently transfected HeLa cells were treated in the absence or presence of a ligand for $24 \mathrm{~h}$. Graphs depict the mean of three independent experiments performed in duplicate. The S.E.M., which was $<15 \%$ of the mean, is not shown for simplicity. (E) The effects of ligands on transcription by $E R \alpha_{A F 2}$ and $E R \alpha_{E B D}+A F 2$ with $(G)$ or without GFP. Cells were transfected with the 2XERE or the MMP1-Luc promoter reporter vector emulating the ERE-dependent or ERE-independent signaling pathway. Cells were also co-transfected with a vector expressing $E R \alpha_{A F 2}$ and $E R \alpha_{E B D}+A F 2$ with $(G)$ or without GFP. Cells were then treated in the absence or presence of a ligand for $24 \mathrm{~h}$ for the luciferase activity for $24 \mathrm{~h}$. Graphs represent the mean of three independent experiments performed in duplicate. The S.E.M., which was $<15 \%$ of the mean, is not shown.

compartment, $\mathrm{E}_{2}$ or $4 \mathrm{HT}$ decreases $\mathrm{ER} \alpha$ mobility by increasing ER $\alpha$-ERE interactions. We therefore suggest that $\mathrm{ER} \alpha$ in response to $\mathrm{E}_{2}$ and $4 \mathrm{HT}$ mediates transcriptions from the ERE-independent pathway with remarkably fast kinetics that contributes fractionally to the overall motility of the receptor. On the other hand, the ligand-mediated mobility of ER $\beta$ is independent of the nature of ligands or the mode of interaction with target sites. It therefore appears that although ERs interact with target sites with fast kinetics, they use distinct mechanisms to regulate transcriptions at signaling pathways.

We show here, as previous studies (Sharp et al. 2006, Zwart et al. 2010), that $4 \mathrm{HT}$, as $\mathrm{E}_{2}$, decreases the mobility of ER $\alpha$ by enhancing ER $\alpha$-ERE interactions (Shang et al. 2000, Huang et al. 2005b). However, the underlying mechanism(s) remains unclear. The binding of tamoxifen to $\mathrm{ER} \alpha$ alters conformation (Paige et al. 1999) that affects co-activator recruitment (Yi et al. 2002b). Tamoxifen-ER $\alpha$ can also recruit co-repressors for transcription repression (Lavinsky et al. 1998, Delage-Mourroux et al. 2000, Shang et al. 2000). While $4 \mathrm{HT}$ is an antagonist for $\mathrm{ER} \alpha$ in HeLa cells, it acts as an agonist in MDA-MB-231 cells (Bentrem et al. 2001, Tonetti et al. 2003). 4HT was also augmented ER $\alpha$-ERE interactions. 4HT-ER $\alpha$ showed mobility similar to $\mathrm{E}_{2}-\mathrm{ER} \alpha$. On the other hand, $\mathrm{ER} \alpha_{\mathrm{EBD}}$ with or without AF2 was kinetically much faster when bound to $4 \mathrm{HT}$ or 
$\mathrm{E}_{2}$ compared with $\mathrm{ER} \alpha$. Our findings therefore imply that $\mathrm{E}_{2^{-}}$and 4HT-mediated decreases in ER $\alpha$ mobility are due to the residency time of the receptor on ERE independent of transcription. By contrast, ICI immobilized ER $\alpha$. ICI binding prevents ER-co-regulator interactions (Yi et al. 2002b) but drives $\mathrm{ER} \alpha$ to interact with cytokeratins through LBD (Long \& Nephew 2006). Leading to the association of ICI-ER $\alpha$ with nuclear matrix (Long \& Nephew 2006, Lupien et al. 2007), this could result in the immobilization and complete prevention of ERE interactions, as shown here and previously (Reid et al. 2003). However, it was also shown that a fraction of ICI-ER $\alpha$ remains associated with the prolactin promoter array, which is composed of 52 prolactin gene promoters containing multiple EREs (Sharp et al. 2006). It is possible that while the majority of $\mathrm{ER} \alpha$ bound to ICI is immobilized to a sub-nuclear region, a fraction of ER $\alpha$ bound to EREs of the promoter array cooperatively and hence stably (Yi et al. 2002b) cannot be readily sequestered away from the array in contrast to the single ERE of the reporter system and the endogenous gene we used here. Another puzzling observation is that while ICI immobilized ER $\alpha$, ICI-ER $\alpha$ still modulated the reporter gene transcription from ERE-independent pathways. Immobilization of ER $\alpha$ by ICI could prevent the interaction of ER with co-regulators/transfactors thereby countering the ER $\alpha$-mediated repressed or activated state of transcriptions.

The changing (Fig. 8) or deletion (Sharp et al. 2006) of critical residues to block AF2 rendered ICI-ER $\alpha$ mobile in cells. This was reflected in the increased extractability of ER $\alpha$ with HSB or detergent likely due to the inability of the receptor to interact with cytokeratins (Long \& Nephew 2006). Nevertheless, ICI-ER $\alpha_{\mathrm{AF} 2}$ was transcriptionally silent despite the fact that the receptor interacted with ERE. Moreover, the increased mobility of $\mathrm{ER} \alpha_{\mathrm{EBD}+\mathrm{AF} 2}$ regardless of the nature of ligand strengthens the conclusion that the duration of ERE occupancy reflects the
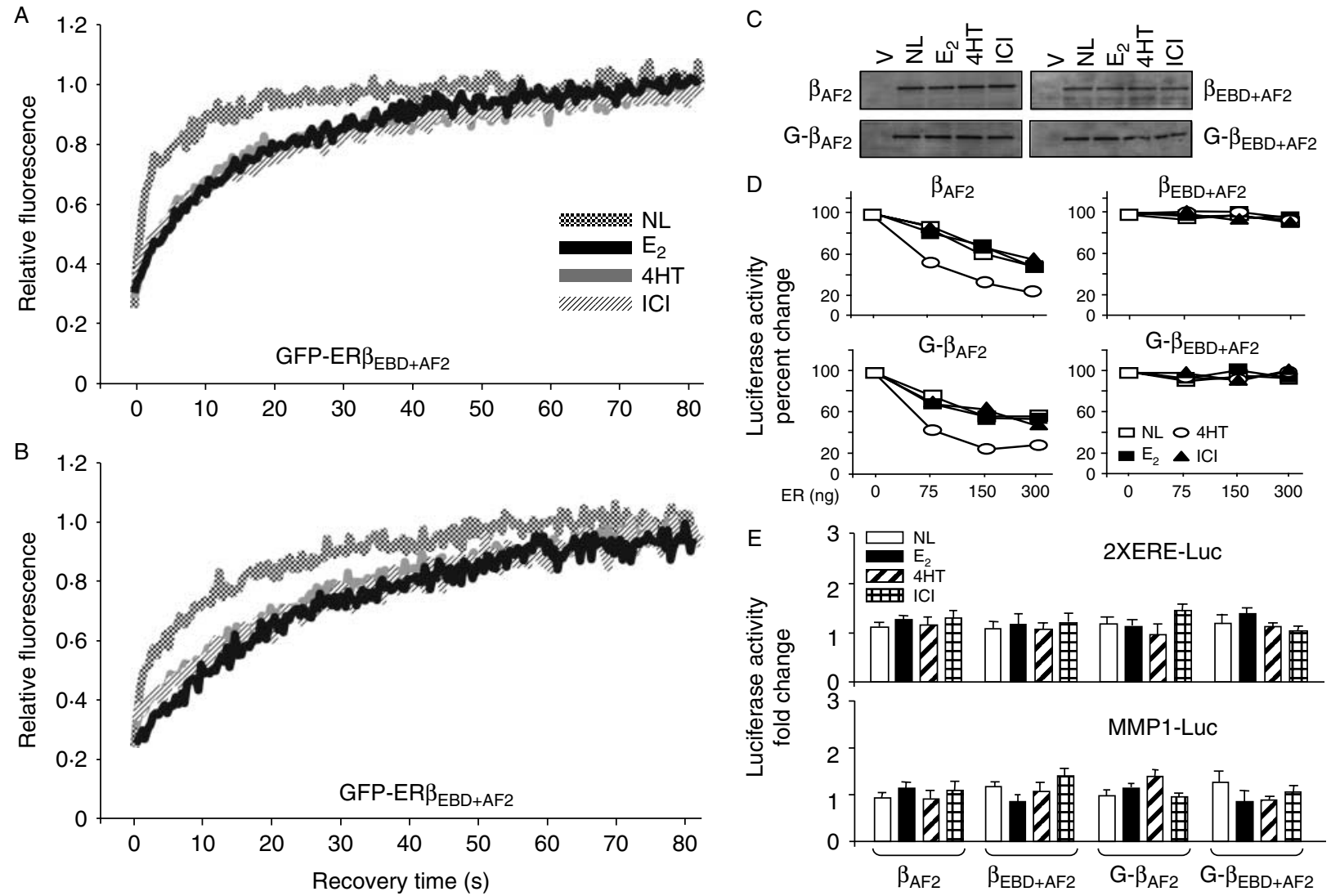

Figure 9 The mobilities of GFP-ER $\beta_{\mathrm{AF} 2}$ and GFP-ER $\beta_{\mathrm{EBD}+\mathrm{AF} 2}$ in HeLa cells. The transfection and processing of cells synthesizing (A) GFP-ER $\beta_{\mathrm{AF} 2}$ or (B) GFP-ER $\beta_{\mathrm{EBD}+\mathrm{AF} 2}$ for FRAP were carried out as described in the legend of Fig. 2. (C) Intracellular level of receptor proteins were analyzed with high salt extracts of transfected HeLa cells, which were treated and processed as described in the legend of Fig. 8C. (D) The effects of ligands on in situ ERE binding abilities of ER $\beta_{A F 2}$ and $E R \beta_{E B D}+A F 2$ with (G) or without GFP were assessed as described in the legend of Fig. 8D. The s.E.M., which was $<15 \%$ of the mean, is not shown for simplicity. (E) The effects of ligands on transcription by $\mathrm{ER} \beta_{\mathrm{AF} 2}$ and $\mathrm{ER} \beta_{\mathrm{EBD}+\mathrm{AF} 2}$ with $(\mathrm{G})$ or without $\mathrm{GFP}$ were assessed as described in the legend of Fig. $8 \mathrm{E}$. Graphs show the mean of three independent experiments performed in duplicate. The S.E.M., which was $<15 \%$ of the mean, is not shown. 
ligand-mediated mobility of ER $\alpha$ independent of transcription status. This lends further credence to the hit-and-run model of transcription for ER $\alpha$ regardless of signaling pathway.

In contrast to $\mathrm{ER} \alpha, \mathrm{ER} \beta$ and $\mathrm{ER} \beta_{\mathrm{EBD}}$ showed indistinguishable mobility rates independent of the nature of ligands and the ability of the receptor to interact with target sites and cellular context. Consequently, it appears that ER $\beta$ mediates gene transcriptions through the ERE-dependent and ERE-independent signaling pathways with similar kinetics. ERs share structural features reflected in similar functional properties. ERs nevertheless exhibit distinct transregulatory potentials at signaling pathways. The amino-termini are critical regions that contribute to subtype-specific transcriptional responses. In contrast to $\mathrm{ER} \alpha$, the $\mathrm{ER} \beta$ amino-terminus impairs ER-ERE interactions (Huang et al. 2005b), lacks an AF (Cowley \& Parker 1999, Yi et al. 2002a), and does not interact with the carboxyl-terminus (Yi et al. 2002a). However, the amino-termini do not appear to contribute to distinct receptor mobility. We observed that the mobilities of the $E R \alpha_{N} \beta_{C}$ chimeras were kinetically similar to those observed with $\mathrm{ER} \beta$ variants. $\mathrm{ER} \beta_{\mathrm{N}} \alpha_{\mathrm{C}}$, on the other hand, mimicked $\mathrm{ER} \alpha$ mobility in response to ligands. These imply that the carboxyl-termini are critical regions in defining mobility differences of ERs. Studies also showed that the carboxyl-termini contribute to transcriptional potencies of ERs (Yi et al. $2002 a$ ) by differentially interacting with co-regulators (Seol et al. 1998, Kressler et al. 2002). Moreover, some co-regulator interactions with ERs are specific to the nature of the ligand. The unliganded ER $\alpha$ interacts with co-repressors SMRT/NCoR (Lavinsky et al. 1998, Webb et al. 2003). The binding of $\mathrm{E}_{2}$ releases co-repressors from ER $\alpha$ (Lavinsky et al. 1998, Webb et al. 2003). The unliganded ER $\beta$ also interacts with SMRT/NCoR through the carboxyl-terminus (Webb et al. 2003). However, the binding of $\mathrm{E}_{2}$ does not promote co-repressor dissociations (Webb et al. 2003). By contrast, the binding of $4 \mathrm{HT}$ or ICI releases SMRT/ NCoR from ER $\beta$ but not from ER $\alpha$ (Lavinsky et al. 1998, Webb et al. 2003). As ER $\beta$ requires $\mathrm{E}_{2}$ to regulate transcription from the ERE-dependent signaling pathway, $\mathrm{E}_{2}$ binding could act as a switch to convert ER $\beta$ to an active state by concurrently recruiting co-activators likely through a distinct surface.

We also found that $4 \mathrm{HT}$ enhanced the ER $\beta$-ERE interaction in contrast to $\mathrm{E}_{2}$ or ICI. Although is unclear, distinct trans-conformational changes in ER $\beta$-DBD mediated by the binding of $4 \mathrm{HT}$ to LBD could underlie the effect of $4 \mathrm{HT}$ on ER $\beta$-ERE interactions. We observed that $4 \mathrm{HT}$ - or ICI-bound $\mathrm{ER} \beta$, as $\mathrm{ER} \beta_{\mathrm{AF} 2}$, showed mobility similar to $\mathrm{E}_{2}-\mathrm{ER} \beta$ despite the fact that the receptor was transcriptionally inactive at the ERE-dependent pathway. Furthermore, ER $\beta_{\mathrm{EBD}}$ mobility was indistinguishable from that of ER $\beta$ independently of ligands. However, $\mathrm{ER} \beta_{\mathrm{EBD}+\mathrm{AF}}$ showed slower mobility than ER $\beta_{\mathrm{EBD}}$. This suggests that the cooperation of AF2 with the ability of the receptor to interact with target sites is a critical feature for the nuclear mobility of ER $\beta$.

In summary, our results indicate that while ERs use a hit-and-run mode of action, they differ mechanistically to modulate transcriptions. The use of integrated promoter arrays mimicking various signaling pathways would yield further insights into mechanisms of ER actions. This in turn could aid in the development of better strategies to combat estrogen target tissue malignancies.

\section{Supplementary data}

This is linked to the online version of the paper at http://dx.doi.org/ 10.1530/JME-12-0097.

\section{Declaration of interest}

The authors declare that there is no conflict of interest that could be perceived as prejudicing the impartiality of the research reported.

\section{Funding}

The work was supported by a grant from NIH CA113682 (M M).

\section{Acknowledgements}

The authors express their gratitude to Melinda Huang and Aja Kalkanoglu for their help in western blot analyses. They also thank Drs James McGrath and Thomas R Gaborski for the establishment of FRAP assays and Brian Fluharty for preliminary studies.

\section{References}

An J, Ribeiro RC, Webb P, Gustafsson JA, Kushner PJ, Baxter JD \& Leitman DC 1999 Estradiol repression of tumor necrosis factor- $\alpha$ transcription requires estrogen receptor activation function-2 and is enhanced by coactivators. PNAS 96 15161-15166. (doi:10.1073/ pnas.96.26.15161)

Ansari KI, Hussain I, Kasiri S \& Mandal SS 2012 HOXC10 is overexpressed in breast cancer and transcriptionally regulated by estrogen via involvement of histone methylases MLL3 and MLL4. Journal of Molecular Endocrinology 48 61-75. (doi:10.1530/JME-110078)

Bentrem D, Dardes R, Liu H, MacGregor-Schafer J, Zapf J \& Jordan V 2001 Molecular mechanism of action at estrogen receptor $\alpha$ of a new clinically relevant antiestrogen (GW7604) related to tamoxifen. Endocrinology 142 838-846. (doi:10.1210/en.142.2.838)

Bjornstrom L \& Sjoberg M 2002 Mutations in the estrogen receptor DNA-binding domain discriminate between the classical mechanism of action and cross-talk with Stat5b and activating protein 1 (AP-1). Journal of Biological Chemistry 277 48479-48483. (doi:10.1074/jbc.C200570200) 
Cowley SM \& Parker MG 1999 A comparison of transcriptional activation by $\mathrm{ER} \alpha$ and ER $\beta$. Journal of Steroid Biochemistry and Molecular Biology 69 165-175. (doi:10.1016/S09600760(99)00055-2)

Damdimopoulos AE, Spyrou G \& Gustafsson JA 2008 Ligands differentially modify the nuclear mobility of estrogen receptors $\alpha$ and $\beta$. Endocrinology 149 339-345. (doi:10.1210/en.2007-0198)

Dauvois S, Danielian PS, White R \& Parker MG 1992 Antiestrogen ICI 164,384 reduces cellular estrogen receptor content by increasing its turnover. PNAS 89 4037-4041. (doi:10.1073/pnas.89.9.4037)

Delage-Mourroux R, Martini PG, Choi I, Kraichely DM, Hoeksema J \& Katzenellenbogen BS 2000 Analysis of estrogen receptor interaction with a repressor of estrogen receptor activity (REA) and the regulation of estrogen receptor transcriptional activity by REA. Journal of Biological Chemistry 275 35848-35856. (doi:10.1074/ jbc.M001327200)

DeNardo DG, Cuba VL, Kim H, Wu K, Lee AV \& Brown PH 2007 Estrogen receptor DNA binding is not required for estrogeninduced breast cell growth. Molecular and Cellular Endocrinology 277 13-25. (doi:10.1016/j.mce.2007.07.006)

Eckert RL, Mullick A, Rorke EA \& Katzenellenbogen BS 1984 Estrogen receptor synthesis and turnover in MCF-7 breast cancer cells measured by a density shift technique. Endocrinology 114 629-637. (doi:10.1210/endo-114-2-629)

Garcia M, Derocq D, Freiss G \& Rochefort H 1992 Activation of estrogen receptor transfected into a receptor-negative breast cancer cell line decreases the metastatic and invasive potential of the cells. PNAS 89 11538-11542. (doi:10.1073/pnas.89.23.11538)

Hall JM \& McDonnell DP 1999 The estrogen receptor $\beta$-isoform (ER $\beta$ ) of the human estrogen receptor modulates ER $\alpha$ transcriptional activity and is a key regulator of the cellular response to estrogens and antiestrogens. Endocrinology 140 5566-5578. (doi:10.1210/ en.140.12.5566)

Huang J, Li X, Yi P, Hilf R, Bambara RA \& Muyan M 2004 Targeting estrogen responsive elements (EREs): design of potent transactivators for ERE-containing genes. Molecular and Cellular Endocrinology 218 65-78. (doi:10.1016/j.mce.2003.12.005)

Huang J, Li X, Hilf R, Bambara RA \& Muyan M $2005 a$ Molecular basis of therapeutic strategies for breast cancer. Current Drug Targets. Immune, Endocrine and Metabolic Disorders 5 379-396. (doi:10.2174/ 156800805774912944)

Huang J, Li X, Maguire CA, Hilf R, Bambara RA \& Muyan M $2005 b$ Binding of estrogen receptor $\beta$ to estrogen response element in situ is independent of estradiol and impaired by its amino terminus. Molecular Endocrinology 19 2696-2712. (doi:10.1210/me.2005-0120)

Huang Y, Li X \& Muyan M 2011 Estrogen receptors similarly mediate the effects of $17 \beta$-estradiol on cellular responses but differ in their potencies. Endocrine 39 48-61. (doi:10.1007/s12020-010-9411-8)

Kato S, Sasaki H, Suzawa M, Masushige S, Tora L, Chambon P \& Gronemeyer H 1995 Widely spaced, directly repeated PuGGTCA elements act as promiscuous enhancers for different classes of nuclear receptors. Molecular and Cellular Biology 15 5858-5867.

Kressler D, Schreiber SN, Knutti D \& Kralli A 2002 The PGC-1-related protein PERC is a selective coactivator of estrogen receptor $\alpha$. Journal of Biological Chemistry 277 13918-13925. (doi:10.1074/jbc. M201134200)

Kushner PJ, Agard DA, Greene GL, Scanlan TS, Shiau AK, Uht RM \& Webb P 2000 Estrogen receptor pathways to AP-1. Journal of Steroid Biochemistry and Molecular Biology 74 311-317. (doi:10.1016/S09600760(00)00108-4)

Lavinsky RM, Jepsen K, Heinzel T, Torchia J, Mullen TM, Schiff R, Del-Rio AL, Ricote M, Ngo S, Gemsch J et al. 1998 Diverse signaling pathways modulate nuclear receptor recruitment of N-CoR and SMRT complexes. PNAS 95 2920-2925. (doi:10.1073/ pnas.95.6.2920)

Lazennec G, Bresson D, Lucas A, Chauveau C \& Vignon F 2001 ER $\beta$ inhibits proliferation and invasion of breast cancer cells. Endocrinology 142 4120-4130. (doi:10.1210/en.142.9.4120)
Li X, Huang J, Yi P, Bambara RA, Hilf R \& Muyan M 2004 Single-chain estrogen receptors (ERs) reveal that the $\mathrm{ER} \alpha / \beta$ heterodimer emulates functions of the ER $\alpha$ dimer in genomic estrogen signaling pathways. Molecular and Cellular Biology 24 7681-7694. (doi:10.1128/ MCB.24.17.7681-7694.2004)

Li X, Nott SL, Huang Y, Hilf R, Bambara RA, Qiu X, Yakovlev A, Welle S \& Muyan M 2008 Gene expression profiling reveals that the regulation of estrogen-responsive element-independent genes by $17 \beta$-estradiol-estrogen receptor $\beta$ is uncoupled from the induction of phenotypic changes in cell models. Journal of Molecular Endocrinology 40 211-229. (doi:10.1677/JME-07-0049)

Long X \& Nephew KP 2006 Fulvestrant (ICI 182,780)-dependent interacting proteins mediate immobilization and degradation of estrogen receptor- $\alpha$. Journal of Biological Chemistry 281 9607-9615. (doi:10.1074/jbc.M510809200)

Long X, Fan M \& Nephew KP 2010 Estrogen receptor- $\alpha$-interacting cytokeratins potentiate the antiestrogenic activity of fulvestrant. Cancer Biology $\mathcal{E}$ Therapy 9 389-396. (doi:10.4161/cbt.9.5.10926)

Lupien M, Jeyakumar M, Hebert E, Hilmi K, Cotnoir-White D, Loch C, Auger A, Dayan G, Pinard GA, Wurtz JM et al. 2007 Raloxifene and ICI 182,780 increase estrogen receptor- $\alpha$ association with a nuclear compartment via overlapping sets of hydrophobic amino acids in activation function 2 helix 12. Molecular Endocrinology 21 797-816. (doi:10.1210/me.2006-0074)

McDonnell DP 1999 The molecular pharmacology of SERMs. Trends in Endocrinology and Metabolism 10 301-311. (doi:10.1016/S10432760(99)00177-0)

Metivier R, Penot G, Hubner MR, Reid G, Brand H, Kos M \& Gannon F 2003 Estrogen receptor- $\alpha$ directs ordered, cyclical, and combinatorial recruitment of cofactors on a natural target promoter. Cell 115 751-763. (doi:10.1016/S0092-8674(03)00934-6)

Nott SL, Huang Y, Li X, Fluharty BR, Qiu X, Welshons WV, Yeh S \& Muyan M 2009 Genomic responses from the estrogen responsive element-dependent signaling pathway mediated by estrogen receptor $\alpha$ are required to elicit cellular alterations. Journal of Biological Chemistry 284 15277-15288. (doi:10.1074/jbc. M900365200)

Paige LA, Christensen DJ, Gron H, Norris JD, Gottlin EB, Padilla KM, Chang CY, Ballas LM, Hamilton PT, McDonnell DP et al. 1999 Estrogen receptor (ER) modulators each induce distinct conformational changes in ER $\alpha$ and ER $\beta$. PNAS 96 3999-4004. (doi:10.1073/pnas.96.7.3999)

Peekhaus NT, Chang T, Hayes EC, Wilkinson HA, Mitra SW, Schaeffer JM \& Rohrer SP 2004 Distinct effects of the antiestrogen Faslodex on the stability of estrogen receptors- $\alpha$ and $-\beta$ in the breast cancer cell line MCF-7. Journal of Molecular Endocrinology 32 987-995. (doi:10.1677/jme.0.0320987)

Reid G, Hubner MR, Metivier R, Brand H, Denger S, Manu D, Beaudouin J, Ellenberg J \& Gannon F 2003 Cyclic, proteasomemediated turnover of unliganded and liganded ER $\alpha$ on responsive promoters is an integral feature of estrogen signaling. Molecular Cell 11 695-707. (doi:10.1016/S1097-2765(03)00090-X)

Safe S 2001 Transcriptional activation of genes by $17 \beta$-estradiol through estrogen receptor-Sp1 interactions. Vitamins and Hormones 62 231-252. (doi:10.1016/S0083-6729(01)62006-5)

Sathya G, Yi P, Bhagat S, Bambara RA, Hilf R \& Muyan M 2002 Structural regions of $\mathrm{ER} \alpha$ critical for synergistic transcriptional responses contain co-factor interacting surfaces. Molecular and Cellular Endocrinology 192 171-185. (doi:10.1016/S03037207(01)00673-6)

Schwabe JW, Chapman L, Finch JT \& Rhodes D 1993 The crystal structure of the estrogen receptor DNA-binding domain bound to DNA: how receptors discriminate between their response elements. Cell 75 567-578. (doi:10.1016/0092-8674(93)90390-C)

Seol W, Hanstein B, Brown M \& Moore DD 1998 Inhibition of estrogen receptor action by the orphan receptor SHP (short heterodimer partner). Molecular Endocrinology 12 1551-1557. (doi:10.1210/ me.12.10.1551) 
Shang Y, Hu X, DiRenzo J, Lazar MA \& Brown M 2000 Cofactor dynamics and sufficiency in estrogen receptor-regulated transcription. Cell 103 843-852. (doi:10.1016/S0092-8674(00)00188-4)

Sharp ZD, Mancini MG, Hinojos CA, Dai F, Berno V, Szafran AT, Smith KP, Lele TP, Ingber DE \& Mancini MA 2006 Estrogenreceptor- $\alpha$ exchange and chromatin dynamics are ligand- and domain-dependent. Journal of Cell Science 119 4101-4116. (doi:10.1242/jcs.03161)

Stenoien DL, Mancini MG, Patel K, Allegretto EA, Smith CL \& Mancini MA 2000 Subnuclear trafficking of estrogen receptor- $\alpha$ and steroid receptor coactivator-1. Molecular Endocrinology 14 518-534. (doi:10.1210/me.14.4.518)

Stenoien DL, Nye AC, Mancini MG, Patel K, Dutertre M, O'Malley BW, Smith CL, Belmont AS \& Mancini MA $2001 a$ Ligand-mediated assembly and real-time cellular dynamics of estrogen receptor $\alpha$-coactivator complexes in living cells. Molecular and Cellular Biology 21 4404-4412. (doi:10.1128/MCB.21.13.4404-4412.2001)

Stenoien DL, Patel K, Mancini MG, Dutertre M, Smith CL, O'Malley BW \& Mancini MA $2001 b$ FRAP reveals that mobility of oestrogen receptor- $\alpha$ is ligand- and proteasome-dependent. Nature Cell Biology 3 15-23. (doi:10.1038/35050515)

Sun G, Porter W \& Safe S 1998 Estrogen-induced retinoic acid receptor $\alpha 1$ gene expression: role of estrogen receptor-Sp1 complex. Molecular Endocrinology 12 882-890. (doi:10.1210/ me.12.6.882)

Tamrazi A, Carlson KE, Daniels JR, Hurth KM \& Katzenellenbogen JA 2002 Estrogen receptor dimerization: ligand binding regulates dimer affinity and dimer dissociation rate. Molecular Endocrinology 16 2706-2719. (doi:10.1210/me.2002-0250)

Tamrazi A, Carlson KE, Rodriguez AL \& Katzenellenbogen JA 2005 Coactivator proteins as determinants of estrogen receptor structure and function: spectroscopic evidence for a novel coactivatorstabilized receptor conformation. Molecular Endocrinology 19 1516-1528. (doi:10.1210/me.2004-0458)

Tonetti DA, Rubenstein R, DeLeon M, Zhao H, Pappas SG, Bentrem DJ, Chen B, Constantinou A \& Craig Jordan V 2003 Stable transfection of an estrogen receptor $\beta$ cDNA isoform into MDA-MB-231 breast cancer cells. Journal of Steroid Biochemistry and Molecular Biology 87 47-55. (doi:10.1016/j.jsbmb.2003.07.003)

Tzukerman MT, Esty A, Santiso-Mere D, Danielian P, Parker MG, Stein RB, Pike JW \& McDonnell DP 1994 Human estrogen receptor transactivational capacity is determined by both cellular and promoter context and mediated by two functionally distinct intramolecular regions. Molecular Endocrinology 8 21-30. (doi:10.1210/me.8.1.21)

Webb P, Lopez GN, Uht RM \& Kushner PJ 1995 Tamoxifen activation of the estrogen receptor/AP-1 pathway: potential origin for the cell-specific estrogen-like effects of antiestrogens. Molecular Endocrinology 9 443-456. (doi:10.1210/me.9.4.443)

Webb P, Valentine C, Nguyen P, Price RH Jr, Marimuthu A, West BL, Baxter JD \& Kushner PJ 2003 ER $\beta$ binds N-CoR in the presence of estrogens via an LXXLL-like motif in the N-CoR C-terminus. Nuclear Receptor 1 4. (doi:10.1186/1478-1336-1-4)

Yi P, Bhagat S, Hilf R, Bambara RA \& Muyan M 2002a Differences in the abilities of estrogen receptors to integrate activation functions are critical for subtype-specific transcriptional responses. Molecular Endocrinology 16 1810-1827. (doi:10.1210/ me.2001-0323)

Yi P, Driscoll MD, Huang J, Bhagat S, Hilf R, Bambara RA \& Muyan M $2002 b$ The effects of estrogen-responsive element- and ligandinduced structural changes on the recruitment of cofactors and transcriptional responses by ER $\alpha$ and ER $\beta$. Molecular Endocrinology 16 674-693. (doi:10.1210/me.16.4.674)

Zajchowski DA, Sager R \& Webster L 1993 Estrogen inhibits the growth of estrogen receptor-negative, but not estrogen receptor-positive, human mammary epithelial cells expressing a recombinant estrogen receptor. Cancer Research 53 5004-5011.

Zhao C, Dahlman-Wright K \& Gustafsson JA 2010 Estrogen signaling via estrogen receptor $\beta$. Journal of Biological Chemistry 285 39575-39579. (doi:10.1074/jbc.R110.180109)

Zwart W, de Leeuw R, Rondaij M, Neefjes J, Mancini MA \& Michalides R 2010 The hinge region of the human estrogen receptor determines functional synergy between AF-1 and AF-2 in the quantitative response to estradiol and tamoxifen. Journal of Cell Science 123 1253-1261. (doi:10.1242/jcs.061135)

Received in final form 18 September 2012 Accepted 26 September 2012 Made available online as an Accepted Preprint 26 September 2012 